OPEN ACCESS

Edited by:

Rajesh Jeewon,

University of Mauritius, Mauritius

Reviewed by:

Marie Desnos-Ollivier,

Institut Pasteur, France

Alexandre Alanio,

Université Paris Diderot, France

*Correspondence: Kandeeparoopan Prasannath prasannathk@esn.ac.lk

Specialty section: This article was submitted to

Fungal Pathogenesis,

a section of the journal

Frontiers in Cellular

and Infection Microbiology

Received: 29 August 2020

Accepted: 25 November 2020

Published: 11 January 2021

Citation:

Hariharan G and Prasannath K (2021)

Recent Advances in Molecular

Diagnostics of Fungal Plant

Pathogens: A Mini Review.

Front. Cell. Infect. Microbiol. 10:600234.

do: $10.3389 /$ fcimb.2020.600234

\section{Recent Advances in Molecular Diagnostics of Fungal Plant Pathogens: A Mini Review}

\author{
Ganeshamoorthy Hariharan and Kandeeparoopan Prasannath * \\ Department of Agricultural Biology, Faculty of Agriculture, Eastern University, Chenkalady, Sri Lanka
}

Phytopathogenic fungal species can cause enormous losses in quantity and quality of crop yields and this is a major economic issue in the global agricultural sector. Precise and rapid detection and identification of plant infecting fungi are essential to facilitate effective management of disease. DNA-based methods have become popular methods for accurate plant disease diagnostics. Recent developments in standard and variant polymerase chain reaction (PCR) assays including nested, multiplex, quantitative, bio and magnetic-capture hybridization PCR techniques, post and isothermal amplification methods, DNA and RNA based probe development, and next-generation sequencing provide novel tools in molecular diagnostics in fungal detection and differentiation fields. These molecular based detection techniques are effective in detecting symptomatic and asymptomatic diseases of both culturable and unculturable fungal pathogens in sole and co-infections. Even though the molecular diagnostic approaches have expanded substantially in the recent past, there is a long way to go in the development and application of molecular diagnostics in plant diseases. Molecular techniques used in plant disease diagnostics need to be more reliable, faster, and easier than conventional methods. Now the challenges are with scientists to develop practical techniques to be used for molecular diagnostics of plant diseases. Recent advancement in the improvement and application of molecular methods for diagnosing the widespread and emerging plant pathogenic fungi are discussed in this review.

\section{Keywords: polymerase chain reaction, molecular identification, next-generation sequencing, fungal plant diseases,} emerging fungal pathogens

\section{INTRODUCTION}

Fungal plant pathogens are among the foremost biotic factors that cause devastating disease in crops (Doehlemann et al., 2017). About 8,000 species of fungi and oomycetes are linked with diseases in plants (Horst, 2008; Fisher et al., 2020). Pathogenic fungi infect plants at any phase from the seedling stage to the seed maturing stage under natural environmental conditions, either alone or in concert with other kinds of phytopathogens (Narayanasamy, 2011). The most common diseases caused by plant pathogenic fungi are anthracnose, blight, canker, damping off, dieback, gall, leaf spot, powdery mildew, rust, root rot, scab, and wilt (Iqbal et al., 2018; Hussain and Usman, 2019; Jain et al., 2019). These diseases can generate significant losses in yield (Godfray et al., 2016), quality 
and quantity (Shuping and Eloff, 2017) in various agricultural systems (Rodriguez-Moreno et al., 2018) of economically important agronomical (Leonard and Szabo, 2005; Asibi et al., 2019), horticultural (Agrios, 2009; Wenneker and Thomma, 2020), floricultural and ornamental (Darras, 2016; Lecomte et al., 2016), and forest (Ritz, 2005; Marčiulynas et al., 2020) plant species worldwide (Malcolm et al., 2013).

The increasing world population necessitates well-organized plant disease management and control in agriculture to assure food security and safety (FAO et al., 2018; Sarrocco and Vannacci, 2018). An efficient and effective framework for early alert and quick response is a crucial element to combat against phytopathogenic fungi (Sankarana et al., 2010; Nagrale et al., 2016). Diagnosis of fungal plant pathogen is of significance in the area of plant protection as it contributes to improving crop vigor and health. Therefore, fungal disease management requires accurate diagnosis of diseases which is chiefly based on the identification of causative agents. Moreover, it is essential to confirm fungal plant diseases even though the diagnosis of such diseases based on the external symptoms is already made to a satisfactory level. Further, an entire list that covers a known plant disease, its typical sign and symptoms, and its known potential phytopathogen for a precise host is a requisite for disease diagnosis (Thind, 2015).

Various advances have been made in the field of phytopathogenic fungal diagnosis. Conventional fungal disease diagnostic methods have utilized visible signs after phytofungal infections including propagules of fungi viz. conidia, sclerotia, or mycelia on the external surfaces of flora, or fungal disease symptoms caused by fungal pathogens after infection (Nezhad, 2014; Tör and Woods-Tör, 2017). These approaches are the cornerstone of fungal disease diagnostics. Widely used conventional methods include isolation and culturing, reinoculation, microscopic techniques and biochemical tests (Tan et al., 2008; Sharma and Sharma, 2016), which have some drawbacks in that they are tedious and require knowledge and expertise in fungal plant pathology and taxonomy (McCartney et al., 2003; Pryce et al., 2003). Immunological-based diagnostic methods are built on the antigen-antibody binding principle and some issues have been noted, such as low sensitivity and affinity in assays, and potential interference from contaminants (Meng and Doyle, 2002). Furthermore, detection of fungal plant pathogens has not been effective due to the high inconsistency and phenotypic serological plasticity of fungi (Luchi et al., 2020). Thus, the implementation and development of novel and effective diagnostic methods to thwart fungal plant disease are urgent. For these reasons, plant-fungal diagnosis has moved to molecular approaches that facilitate pathogen recognition and quantification. Molecular assays can overcome drawbacks of conventional and serological methods in fungal diagnostics.

Modern developments use high throughput molecular detection strategies for plant infecting fungi. These include standard polymerase chain reaction (PCR), real-time PCR, nested PCR, loop-mediated isothermal amplification (LAMP), rolling circle amplification (RCA), and nucleic acid sequencebased amplification (NASBA) (Aslam et al., 2017; Cheng et al., 2020). PCR restriction fragment length polymorphism
(PCR-RFLP) and PCR denaturing-gradient gel electrophoresis (PCR-DGGE) are the methods suitable for genotyping more than for species identification (Johnston-Monje and Mejia, 2020). Further, molecular techniques cover magnetic capturehybridization PCR (MCH-PCR), in situ PCR, co-operational PCR, multiplex PCR, DNA macro and micro arrays, nextgeneration sequencing (especially RNA-Seq based), etc. (Kumar et al., 2016). Greater confidence, accuracy, specificity, and sensitivity of DNA based molecular techniques (Capote et al., 2012; Midorikawa et al., 2018) permit the diagnosis of phytopathogens at primary stages of infection even though they are present at lower DNA concentrations (Luchi et al., 2013; Rollins et al., 2016).

Additionally, bioinformatics databases such as GenBank at the National Centre for Biotechnology Information (NCBI), Nucleotide Sequence Database Collaboration at the European Bioinformatics Institute (EBI), MycoBank, etc. offer platforms for documenting mycological nomenclatural novelties, storing and retrieving facilities of nucleotide sequences of plant infecting fungi which further accelerate the molecular tools to potentially diagnose and perform species delimitation among existing and evolving fungal species. Rapidly emerging and novel fungal plant pathogens threaten the global economy. Hence, rapid and accurate detection and identification of phytopathogenic fungi is crucial. This review aims to summarize various molecular techniques in fungal plant pathogen diagnosis along with their advantages and drawbacks. It also examines the available molecular tools used to diagnose previously present, emerging, and re-emerging plant pathogenic fungi in various agricultural crops.

\section{MOLECULAR TOOLS FOR DETECTION OF FUNGI}

\section{Preanalytical Steps in Molecular-Based Diagnosis of Plant-Infecting Fungi}

Detection and diagnosis of fungal plant pathogens using molecular techniques require preanalytical steps such as genomic DNA extraction that efficiently lyse fungal cells and recover the DNA, purification and quantification of extracted DNA. Several protocols for isolation of DNA from plant infecting fungi are available (Doyle, 1991; Cenis, 1992; Chi et al., 2009; Zhang et al., 2010; Gontia-Mishra et al., 2014; Yang et al., 2016). Recent fungal plant disease diagnostic approaches use commercial DNA extraction kits (Martinelli et al., 2015; Moffat et al., 2015). However, laboratories are dependent on standard protocols embracing lyophilization of mycelia, disruption of chitin cell wall by grinding and isolation of DNA in a buffer containing chemicals, removal of proteins by phenol-chloroform mixture, and precipitation with propanol. The isolated fungal DNA can then be purified using standard methods including pelleting, silica membrane (Mancini et al., 2016), spin filter, and silica coated magnetic particle separation (Tsui et al., 2011). Finally, the concentration of fungal DNA in the samples can be determined using UV spectrophotometer and 
further it can be diluted with ultrapure PCR grade water to provide an appropriate DNA concentration (Abdullah et al., 2018).

\section{Polymerase Chain Reaction (PCR) Based Assays \\ End-Point PCR}

Advent of PCR revolutionized the accurate identification of various plant pathogens in disease management, including fungi (Ma and Michailides, 2007). In this in vitro technique, a piece of DNA template is exponentially amplified (CaetanoAnolles, 2013) through repeated cycles of denaturation, annealing, extension, final extension, and final hold reactions at various temperatures using specific primers, deoxyribonucleotide triphosphates (dNTPs), and a thermostable Taq DNA polymerase in buffer solution (Griffiths, 2014). In end-point PCR, designing either specific oligonucleotides that target certain fungal species or universal primers to amplify multiple pathogens followed by sequencing allows the accurate detection of fungal plant pathogens. For each set of nucleotide sequences of fungal isolates, the identity of each isolate can be determined by comparison against ex-type cultures available in the NCBI GenBank database using Basic Local Alignment Search Tool (BLAST) analysis. The presence of a target revealed in agarose gel electrophoresis assures the existence of targeted phytopathogenic fungi (Mirmajlessi et al., 2015).

End-point PCR systems are considered a cost-effective choice compared to other existing molecular diagnosis options for fungal plant pathogens. However, end-point PCR assays can be time-consuming and it is difficult to design primer sets to delineate closely-related fungal pathogens. Sikdar et al. (2014) dealt with diagnosing Phacidiopycnis washingtonensis and Sphaeropsis pyriputrescens (which cause speck rot and Sphaeropsis rot diseases in apple, respectively) using end-point PCR and real-time PCR assays. They found that the quantitative real-time PCR approach was more sensitive than the end-point PCR approach for rapid diagnosis. Different types of PCR-based molecular diagnosis and examples of each type are given in Table 1.

\section{Nested PCR}

Nested PCR is a modified version of end-point PCR that uses two sets of primer pairs aimed at two rounds of PCR amplification to enhance specificity and sensitivity. Nesting also aids usage of comparatively non-specific PCR primers in the initial round of PCR for amplification of numerous pathogens, followed by the use of pathogen-specific primers in the next round (Bhat and Browne, 2010). Twig blight and crown rot of pomegranate are emerging diseases in pomegranate cultivation that are caused by Pilidiella granati. A nested PCR assay improved both sensitivity and detection of $P$. granati and made it possible to diagnose the causative agent when the sample contained DNA as low as $10 \mathrm{pg}$ of P. granati (Yang X. et al., 2017). Great yam disease caused by Colletotrichum gloeosporioides (Raj et al., 2013) and eucalyptus dieback disease caused by Cylindrocladium scoparium (Qiao et al., 2016) were also detected by this technique. Sensitivity of detection using nested PCR could be enhanced from 10- to 1000fold over an end-point PCR assay (Ippolito et al., 2002; Silvar et al., 2005). However, nested PCR assays are time-consuming and have an increased risk of cross-contamination due to the manipulation of previously-amplified samples, which can create false-positive outcomes (Raj et al., 2013). Therefore, nested PCR and end-point PCR methods that may produce amplicon contamination would not be recommended to be used as reliable diagnostic methods.

\section{Multiplex PCR}

Multiplex PCR assay uses one reaction mixture with various primer pairs, and allows simultaneous amplification of several pathogens (Sint et al., 2012). The generated amplicons can then be separated and visualized using electrophoresis. Designing primers for the multiplex assay is crucial, and specific sets of primers should have similar annealing temperatures for successful amplification (Zhao X et al., 2014). A concurrent diagnostic assay to detect 12 fungi associated with fruit rot in cranberry was established using the multiplex PCR method. Fungal pathogens Allantophomopsis cytisporea, A. lycopodina, Phyllosticta elongate, Coleophoma empetri, Colletotrichum fiorinae, C. fructivorum, Fusicoccum putrefaciens, Monilinia oxycocci, Phomopsis vaccinia, Phyllosticta vaccinia, Physalospora vaccinia, and Strasseria geniculate linked with cranberry fruit rot were effectively identified with the use of ITS-LSU and TEF-1 $\alpha$ gene regions (Conti et al., 2019). The pathogenic fungi Fusarium oxysporum, Bipolaris cactivora, Phytophthora nicotinae, and Phytophthora cactorum are threats to the cactus industry that potentially affect its export sector. This problem has been resolved using multiplex PCR assays. It was noted that the diagnosing tool was sufficient to detect and identify these quarantine fungal pathogens in grafted cacti (Cho et al., 2016). Though multiplex PCR assays are quick and reliable in nature, the assays are potentially expensive and resource-intensive, and decreased sensitivity associated with the multiplex methods (Pallás et al., 2018).

\section{Quantitative PCR}

Quantitative PCR (qPCR), permits detection and quantification of particular DNA or RNA sequences of phytopathogenic fungi in a PCR reaction mixture in real-time. The relative number of copies of target DNA and RNA sequences can be estimated by projecting a $C t$ (cycle threshold) value of the fungal samples using sequence-specific primers (Balodi et al., 2017). Fluorescent dyes such as SYBR Green I, Eva Green, Molecular Beacons, or sequence-specific fluorescence-labeled reporter probes such as TaqMan (Badali and Nabili, 2012) are used to monitor the reaction during amplification steps. The basic principle is that the fluorescent signal is proportional to the amount of amplicon produced in each cycle and can be generated by an intercalating dye or from the breakdown of a dye-labeled reporter probe during amplification (Alemu, 2014). A hypervirulent and emerging fungal plant pathogen, Cryphonectria parasitica causes various diseases (blight, lethal bark cankers, wilting, and 
TABLE 1 | PCR based approaches to diagnose pathogenic fungi in different crops.

\begin{tabular}{|c|c|c|c|c|c|}
\hline Assay & Diagnosed fungi & Host & Disease & Target gene $^{a}$ & Reference \\
\hline End-point PCR & Cercospora tezpurensis sp. nov. & $\begin{array}{l}\text { Capsicum } \\
\text { assamicum }\end{array}$ & Leaf spot & $\begin{array}{l}\text { ACT, CAL, HIS and } \\
\text { TEF- } 1 \alpha\end{array}$ & $\begin{array}{l}\text { Meghvansi et al., } \\
2013\end{array}$ \\
\hline End-point PCR & Exobasidium maculosum & Blueberry & Leaf and fruit spot & LSU-rDNA & Brewer et al., 2014 \\
\hline End-point PCR & $\begin{array}{l}\text { Golovinomyces cichoracearum sensu } \\
\text { lato }\end{array}$ & Cannabis sativa & Hemp powdery mildew & ITS & Pépin et al., 2018 \\
\hline End-point PCR & Cercospora cf. flagellaris & Cannabis sativa & Hemp leaf spot & $\begin{array}{l}\text { ITS, TEF-1 } \alpha, C A L, H I S \\
\text { and } A C T\end{array}$ & Doyle et al., 2019 \\
\hline End-point PCR & $\begin{array}{l}\text { Neopestalotiopsis clavispora and } \\
\text { Colletotrichum siamense }\end{array}$ & Macadamia & Leaf spot & $\begin{array}{l}\text { ITS, TUB2, TEF- } 1 \alpha \\
\text { ACT and GAPDH }\end{array}$ & $\begin{array}{l}\text { Prasannath et al., } \\
2020\end{array}$ \\
\hline Nested PCR & Puccinia striiformis f. sp. tritici & Wheat & Stripe rust & PSR & Wang et al., 2009 \\
\hline Nested PCR & Phytophthora cactorum & Strawberry & Crown rot & ITS & $\begin{array}{l}\text { Bhat and Browne, } \\
2010\end{array}$ \\
\hline Nested PCR & Colletotrichum gloeosporioides & Dioscorea spp. & Greater yam anthracnose & ITS & Raj et al., 2013 \\
\hline Nested PCR & Pilidiella granati & Pomegranate & $\begin{array}{l}\text { Twig blight and } \\
\text { crown rot }\end{array}$ & SSU-rDNA & Yang X. et al., 2017 \\
\hline Multiplex PCR & $\begin{array}{l}\text { Fusarium } \\
\text { Verticillioides and F. subglutinans }\end{array}$ & Maize & Stalk rot and ear rot & gaoB & Faria et al., 2012 \\
\hline Multiplex PCR & $\begin{array}{l}\text { Neofabraea alba, } \\
\text { N. perennans and } \\
\text { N. keinholzii }\end{array}$ & Apple & Bull's eye rot & TUB2 & $\begin{array}{l}\text { Michalecka et al., } \\
2016\end{array}$ \\
\hline Multiplex PCR & $\begin{array}{l}\text { Fusarium oxysporum } \mathrm{f} . \\
\text { sp. cubense lineage } \mathrm{VI} \text { strains }\end{array}$ & Musa spp. & Dessert/beer bananas & TEF- $1 \alpha$ and $R P C 2$ & $\begin{array}{l}\text { Ndayihanzamaso } \\
\text { et al., } 2020\end{array}$ \\
\hline Quantitative PCR & Didymella bryoniae & Cucurbits & Gummy stem blight & $R A P D$ & Ling et al., 2010 \\
\hline Quantitative PCR & $\begin{array}{l}\text { Ramularia } \\
\text { collo-cygni }\end{array}$ & Barely & Ramularia leaf spot & Not mentioned & Havis et al., 2014 \\
\hline Quantitative PCR & Rhizoctonia solani & Tobacco & Target spot & ITS & $\begin{array}{l}\text { Zhao Y. Q. et al., } \\
2014\end{array}$ \\
\hline Quantitative PCR & Magnaporthe oryzae & Rice & Rice blast & 18S-28S rDNA & Sun et al., 2015 \\
\hline Quantitative PCR & Verticillium longisporum & Brassica napus & Wilt and stem stripe & TUB2 & Depotter et al., 2017 \\
\hline Quantitative PCR & $\begin{array}{l}\text { Pyrenophora tritici-repentis and } \\
\text { Parastagonospora nodorum }\end{array}$ & Wheat & $\begin{array}{l}\text { Tan (yellow) spot and } \\
\text { Septoria blotch }\end{array}$ & TOXA & Abdulla et al., 2018 \\
\hline Quantitative PCR & Fusarium culmorum & Cereals & $\begin{array}{l}\text { Foot and root rot and Fusarium } \\
\text { head blight }\end{array}$ & COX2 & Bilska et al., 2018 \\
\hline Quantitative PCR & Fusarium guttiforme & Pineapple & Fusariosis & TEF- $1 \alpha$ and TUB2 & $\begin{array}{l}\text { Carnielli-Queiroz } \\
\text { et al., } 2019\end{array}$ \\
\hline $\begin{array}{l}\text { End-point PCR and } \\
\text { quantitative PCR }\end{array}$ & $\begin{array}{l}\text { Phacidiopycnis washingtonensis and } \\
\text { Sphaeropsis pyriputrescens }\end{array}$ & Apple & $\begin{array}{l}\text { Speck rot and } \\
\text { Sphaeropsis rot }\end{array}$ & ITS & Sikdar et al., 2014 \\
\hline $\begin{array}{l}\text { End-point PCR and } \\
\text { quantitative PCR }\end{array}$ & Guignardia citricarpa & Citrus spp. & Citrus black spot & ITS & $\begin{array}{l}\text { Faganello et al., } \\
2017\end{array}$ \\
\hline
\end{tabular}

aITS, internal transcribed spacer; LSU-rDNA, large subunit ribosomal DNA; SSU-rDNA, small subunit ribosomal DNA; TUB2, $\beta$-tubulin 2; TEF-1 $\alpha$, translation elongation factor 1- $\alpha$; GAPDH, glyceraldehyde-3-phosphate dehydrogenase; ACT, actin; CAL, calmodulin; HIS, histone H3; PSR, Puccinia strifformis $f$. sp. tritici repeat sequence; gaoB, galactose oxidase B; RPC2, DNA-directed RNA polymerase III subunit RPC2; RAPD, random amplified polymorphic DNA; ToxA, exotoxin A; COX-2, cyclooxygenase-2.

dieback) in chestnut trees, Castanea dentata and C. sativa (Murolo et al., 2018; Jain et al., 2019). Molecular diagnosis by qPCR allowed the detection of C. parasitica using rDNA ITS sequences with a sensitivity of $2 \mathrm{fg}$ of genomic DNA which was equivalent to the single spore of a pathogen (Chandelier et al., 2019).

An emerging fungal pathogen Ramularia collo-cygni shows typical symptoms of small, brown spots on leaves, sheaths, and awns, which made it difficult to accurately diagnose this disease using conventional techniques (Havis et al., 2015). A qPCR test was developed and submitted as the first report on molecular detection of R. collo-cygni in barley seed (Havis et al., 2014). An aggressive and emerging British Verticillium longisporum is another example of a novel fungal pathogen that was diagnosed with a qPCR approach (Depotter et al., 2017). A qPCR was able to distinguish and quantify Diaporthe helianthi and D. gulyae, the fungal pathogens of Phomopsis stem canker in sunflower. These causative agents from the same genus were successfully screened using the assay (Elverson et al., 2020). Pyrenophora tritici-repentis and Parastagonospora nodorum cause co-infections in wheat and share common physiognomies, making it a challenge for traditional disease diagnosis. Two duallabeled probes with unique fluorogenic reporters (permitting DNA sequences from $P$. triticirepentis and $P a$. nodorum to be amplified in parallel but independently of each other) were custom designed to perform a duplex qPCR assay, and results obtained were accurate and appropriate to simultaneous differentiation and suitable for high throughput screening of multiple pathogens (Abdullah et al., 2018). This technique is fast and very sensitive (Sikdar et al., 2014), and can provide reliable information on pathogen load (Garrido et al., 2009) and high throughput quantification of target DNA in biological areas (Schena et al., 2013). Further, the TaqMan probe offers an extra level of specificity (Shuey et al., 2014). However, qPCR needs a specialized instrument and cost of the instrument and probe can be high (Abdullah et al., 2018). 


\section{BIO-PCR}

BIO-PCR assay is a modification of end-point PCR technique which involves a pre-assay incubation step in a diseased sample to increase the biomass of the causal agent. This technique is mainly used to concentrate target pathogens by growing the target pathogen in a growing media that prevent the growth of non-target microorganisms to improve detection (Schaad et al., 1995) and has been effectively used to detect seed-borne fungal pathogens (Kumar et al., 2020). A seed and airborne lupin anthracnose disease caused by Colletotrichum lupini was diagnosed using the BIO-PCR method. Incubation of the seeds with amended Yeast Malt Broth was done to enrich $C$. lupine biomass and a species-specific primer pair was developed based on rDNA IGS sequence. The established BIO-PCR protocol allowed the detection of $C$. lupine in Lupinus spp. (Pecchia et al., 2019). The seed-borne fungal pathogens Alternaria alternata, A. radicina, and A. dauci were detected using specific primers of ITS in rDNA with the help of a deep-freezeblotter method during the BIO-PCR assay (Konstantinova et al., 2002). High sensitivity, elimination of PCR inhibitors and detection of living cells to avoid false positives are the advantages over endpoint PCR techniques (Marcinkowska, 2002; Fatmi et al., 2005). Limitations of this technique are that it is time consuming and costs are incurred when selective media is used for the assay (Schena et al., 2004; Mancini et al., 2016).

\section{Magnetic-Capture Hybridization PCR}

Magnetic-capture hybridization PCR (MCH-PCR) uses DNA isolation with a purification phase that contains hybridization with single stranded DNA (ssDNA) probe on magnetic beads followed by the PCR amplification of target DNA sequences (Jacobsen, 1995). This PCR assay was chiefly established to deal with PCR inhibitors in plant extracts during DNA isolation steps. The magnetic beads used are coated with a biotinylated oligonucleotide that is specific to a DNA region of the fungal pathogen of interest (Walcott et al., 2004). The hybridization of double stranded DNA (dsDNA) and magnetic beads allows for separation of the complex from inhibitors (Capote et al., 2012). $\mathrm{MCH}$ and real-time based PCR assays were evaluated for two cucurbit seed pathogens, Acidovorax avenae subsp. citrulli and Didymella bryoniae, that cause bacterial fruit blotch and gummy stem blight, respectively. The assay facilitated simultaneous detection of both tested pathogens in cucurbit seed samples ( $\mathrm{Ha}$ et al., 2009). Designing of a capture probe used in MCH-PCR involves selection of oligonucleotide probe sequence from highly conserved regions of fungal pathogens (Langrell and Barbara, 2001). The selected sequence can be examined in silico for specificity using BLAST. The 5' end of the probe is then biotin-labeled (Chen and Griffiths, 2001) to allow attachment with streptavidin-coated magnetic beads (Johnson et al., 2013). MCH-PCR would decrease the total detection time, increase PCR sensitivity, and remove most of the inhibitors of the amplification reaction and excess of nontarget DNA (Amagliani et al., 2006).

\section{Isothermal Amplification Based Methods Rolling Circle Amplification}

Rolling circle amplification (RCA) is an isothermal enzymatic assay that exploits DNA or RNA polymerase to generate ssDNA or RNA molecules. Requirements for an RCA assay are DNA polymerase, homologous buffer, short DNA/RNA primer, a circular template, and deoxynucleotide triphosphates (Gu et al., 2018). In this assay, DNA amplification using phi29 DNA polymerase with a strand displacement activity to extend a single or multiple primers annealing to a circular DNA template is essential (van Emmerik et al., 2020). The strand displacement process allows newly synthesized DNA template to displace the formerly synthesized DNA molecule to release ssDNA (Bhat and Rao, 2020). Long ssDNA with 100- 1,000 tandem repeats of the original targeted sequence are generated after cascade of strand displacement events (Kieser and Budowle, 2020). Four padlock probes PLP-Nm, PLP-Np, PLP-Nk, and PLP-Nv targeted on TEF-1 $\alpha$ segments were designed to identify Neofabraea malicorticis, N. perennans, N. kienholzin, and $N$. vangabunda that cause bull's eye rot in apple. An RCA assay was used to diagnose these pathogens and provided effective and sensitive results to monitor the pathogens in the quarantine sector (Lin et al., 2018). In another study, RCA was performed to detect the Fusarium head blight-causing agent Fusarium graminearum and other pathovars, F. oxysporum, F. incarnatum-equiseti, and F. tricinctum species complex with the use of padlock probes that were designed based on polymorphisms in the elongation factor TEF-1 $\alpha$ (Davari et al., 2012). Simplicity, efficiency, and no need of temperature cycling devices are the advantageous of the RCA assay (Dong et al., 2013; Goo and Kim, 2016). This method can also be used to analyze gene expression, single nucleotide polymorphism, mRNA splicing and post translational modification of protein molecules (Gao et al., 2019).

\section{Loop Mediated Amplification}

Loop mediated amplification (LAMP) technique has become a significant diagnostic tool in various plant disease diagnosis over only a decade and holds huge potential in plant disease management (Le and $\mathrm{Vu}, 2017$ ). The LAMP reaction comprises two main stages including an initial step and cycling amplification, followed by an elongation step (Panno et al., 2020). In a LAMP assay, a set of two internal primers, forward inner primer (FIP) and backward inner primer (BIP), one backward loop primer (B-Loop), and another set of two outer primers (F3 and B3), are used to recognize six unique sequences on the targeted nucleic acid. Each FIP and BIP comprises double distinct sequences corresponding to sense and anti-sense strands of targeted DNA. Inclusion of two extra loop primers such as loop forward (LF) and loop backward (LB) and Bst DNA polymerase may accelerate the LAMP method (Nagamine et al., 2002; Francois et al., 2011). Its high exponential and isothermal amplification yields $10^{9}-10^{10}$ fold target DNA in $45-60 \mathrm{~min}$ at $60-65^{\circ} \mathrm{C}$ and this temperature rage is considered to be ideal for Bst polymerase activity (Notomi et al., 2000; Chander et al., 2014). Examples of various fungal plant disease diagnoses using LAMP are shown in Table 2.

Uromyces betae, sugar beet rust-causing fungi, was identified within 30 min using LAMP assay which targeted the cytochrome $b$ DNA sequence (Kaczmarek et al., 2019). Conventional LAMP (cLAMP) and a quantitative LAMP (qLAMP) assays were 
performed to diagnose a quarantine fungal pathogen Fusarium circinatum that causes pitch canker in pine and other conifers. LAMP probes targeting TEF- $1 \alpha$ revealed that qLAMP tests had higher specificity than CLAMP for the detection of F. circinatum (Stehliková et al., 2020). A widespread pathogen, Sclerotinia sclerotiorum, with a broad host range including rape seed, was detected using a LAMP assay targeting Ssos5 and a visualizing indicator hydroxynaphthol blue (HNB) for detection. The identification limit of $S$. sclerotiorum using the LAMP technique was $0.1 \mathrm{fg}^{-1} \mathrm{l}^{-1}$ of genomic DNA per reaction which was significantly lower $\left(100 \mathrm{fg}^{\mathrm{N}} \mathrm{l}^{-1}\right)$ than the end-point PCR test (Duan Y. et al., 2014). Further, the first LAMP and qLAMP detection systems using MGG_04322 as a target in Magnaporthe oryzae were developed for prompt detection and accurate identification of rice blast disease (Li et al., 2019). Fusarium odoratissimum tropical race 4 (TR4), the cause of panama disease in banana plants, was accurately diagnosed based on a LAMP assay using TR4 markers that were sequenced from diversity arrays technology sequencing (DArTseq) technology (Ordóñez et al., 2019). LAMP allows analysis of crude samples as it is not affected by inhibitors (Panno et al., 2019). This tool is extremely sensitive and specific due to amplification of nucleic acids accomplished by using up to six primers (Becherer et al., 2020). Isothermal and energy efficient intensification requirements of LAMP technology makes it a prime candidate for rapid and inexpensive alternative assays (Waliullah et al., 2020). Thus, LAMP is well established in several areas including medicine, agriculture, and food industries (Mori and Notomi, 2009;

TABLE 2 | LAMP based molecular diagnosis of fungal pathogens in various crops.

\begin{tabular}{|c|c|c|c|c|c|}
\hline Pathogen & Host & Disease & $\begin{array}{l}\text { Target } \\
\text { gene }^{a}\end{array}$ & Detection system & Reference \\
\hline Phytophthora sojae & Soybean & $\begin{array}{l}\text { Phytophthora } \\
\text { root rot }\end{array}$ & AЗаPro & $\begin{array}{l}\text { Real time measurement of turbidity, gel } \\
\text { electrophoresis, and hydroxynaphthol blue (HNB) } \\
\text { visualizing indicator }\end{array}$ & Dai et al., 2012 \\
\hline Verticillium dahliae & Olive & Vascular wilt & RAPD & HNB visualizing indicator & Moradi et al., 2014 \\
\hline Botrytis cinerea & $\begin{array}{l}\text { Fruits and } \\
\text { flowers }\end{array}$ & $\begin{array}{l}\text { Gray mold } \\
\text { disease }\end{array}$ & $B \cos 5$ & HNB visualizing indicator & Duan Y. B. et al., 2014 \\
\hline Fusarium oxysporum f. sp. ciceris & Chick pea & Fusarium wilt & TEF-1 $\alpha$ & HNB visualizing indicator & Ghosh et al., 2015 \\
\hline Colletotrichum falcatum & Sugarcane & Red rot & SCAR & SYBR Green I dye & Chandra et al., 2015 \\
\hline Didymella bryoniae & Cucurbitaceae & $\begin{array}{l}\text { Gummy stem } \\
\text { blight }\end{array}$ & $R A P D$ & $\begin{array}{l}\text { Calcein indicator } \\
\text { and gel image }\end{array}$ & Yao et al., 2016 \\
\hline Plasmopara viticola & Grape & $\begin{array}{l}\text { Grape downy } \\
\text { mildew }\end{array}$ & ITS & HNB visualizing indicator & Kong et al., 2016 \\
\hline $\begin{array}{l}\text { Calonectria osedonaviculata and } \mathrm{C} . \\
\text { henricotiae }\end{array}$ & Box wood & $\begin{array}{l}\text { Boxwood } \\
\text { blight }\end{array}$ & TUB2 & Capillary gel electrophoresis & $\begin{array}{l}\text { Malapi-Wight et al., } \\
\text { 2016a }\end{array}$ \\
\hline Fusarium oxysporum f. sp. Iycopersici & Tomato & Tomato wilt & SIX3 & Melting curve analysis & Ayukawa et al., 2017 \\
\hline Peronospora destructor & Onion & $\begin{array}{l}\text { Downey } \\
\text { mildew }\end{array}$ & ITS & HNB visualizing indicator & Yang K. et al., 2017 \\
\hline Pyrenopeziza brassicae & $\begin{array}{l}\text { Brassica } \\
\text { napus }\end{array}$ & Light leaf spot & $\begin{array}{l}\text { ITS and } \\
\text { TUB2 }\end{array}$ & & King et al., 2018 \\
\hline $\begin{array}{l}\text { Fusarium fujkuroi and Magnaporthe } \\
\text { oryzae }\end{array}$ & Rice & $\begin{array}{l}\text { Bakane and } \\
\text { rice blast }\end{array}$ & $\begin{array}{l}\text { TEF- } 1 \alpha \text { and } \\
\text { CAL }\end{array}$ & Gel electrophoresis & Ortega et al., 2018 \\
\hline Puccinia triticina & Wheat & Leaf rust & PTS68 & HNB visualizing indicator & $\begin{array}{l}\text { Manjunatha et al., } \\
2018\end{array}$ \\
\hline Fusarium fujkuroi & Rice & Bakane & NRPS31 & HNB visualizing indicator & Zhang et al., 2019 \\
\hline Magnaporthe oryzae & Rice & Rice blast & MGG_04322 & HNB visualizing indicator and gel electrophoresis & Li et al., 2019 \\
\hline Ustilago tritici & Wheat & Loose smut & $\begin{array}{l}\text { LSU-rDNA } \\
\text { and ITS }\end{array}$ & Visual observation under natural light and gel imager & Yan et al., 2019 \\
\hline Fusarium oxysporum f. sp. melonis & Melon & Fusarium wilt & TEF-1 $\alpha$ & HNB visualizing indicator & Almasi, 2019 \\
\hline Uromyces betae & Sugar beet & $\begin{array}{l}\text { Sugar beet } \\
\text { rust }\end{array}$ & cyt b & FAM dye & Kaczmarek et al., 2019 \\
\hline Colletotrichum gloeosporioides & Strawberry & Anthracnose & cyt b & HNB visualizing indicator & Wu et al., 2019 \\
\hline Talaromyces flavus & Strawberry & $\begin{array}{l}\text { Not } \\
\text { mentioned }\end{array}$ & $r l f$ & Fluorescence data & Panek and Frąc, 2019 \\
\hline Alternaria spp. & Pear & $\begin{array}{l}\text { Pear black } \\
\text { spot }\end{array}$ & Aacyt-b & SYBR Green I dye & Yang et al., 2019 \\
\hline $\begin{array}{l}\text { Calonectria ilicicola, Dactylonectria } \\
\text { macrodidyma and Dactylonectria } \\
\text { genus }\end{array}$ & Avocado & Black root rot & $\begin{array}{l}\text { TUB2 and } \\
\text { HIS }\end{array}$ & Presence of annealing curve & Parkinson et al., 2019 \\
\hline Phytophthora infestans & Potato & $\begin{array}{l}\text { Potato late } \\
\text { blight }\end{array}$ & PISMC & HNB visualizing indicator & Kong et al., 2020 \\
\hline
\end{tabular}

aITS, internal transcribed spacer; LSU-rDNA, large subunit ribosomal DNA; TUB2, $\beta$-tubulin 2; TEF-1 $\alpha$, translation elongation factor 1- $\alpha$; CAL, calmodulin; HIS, histone H3; PTS68, Puccinia triticina sequence repeat; RAPD, random amplified polymorphic DNA; Bcos5, Botrytis cinerea mitogen-activated protein kinase; SIX3, secreted in xylem 3; NRPS31, nonribosomal peptide synthetase; MGG_04322, A1b1 superfamily hypothetical protein; cyt b, cytochrome b; rlf, DNA replication licensing factor; Aacyt-b, Alternaria alternata cytochrome b; PiSMC, Phytophthora infestans specific multiple copy DNA sequence; SCAR, sequence characterized amplified region; A3aPro, an element in the upstream of the avirulent gene Avr3 in Phytophthora sojae. 
Guan et al., 2010; Panno et al., 2020). The short size of target gene fragments, using six primers that can generate difficulties in experimental design, and the extreme amount of indicator and other reaction constituents that inhibit polymerase and carryover contaminations are considered to be the drawbacks of this diagnostic tool (Tanner et al., 2015).

\section{Nucleic Acid Sequence Based Amplification}

Nucleic acid sequence based amplification (NASBA) amplifies nucleic acids under isothermal conditions. It commonly uses RNA for amplification where a single stranded RNA (ssRNA) template is changed to complementary DNA (cDNA) by reverse transcriptase. The temperature for NASBA is around $41^{\circ} \mathrm{C}$ and the assay utilizes avian byeloblastosis virus reverse transcriptase, RNase $\mathrm{H}$, and T7 RNA polymerase (Chang et al., 2012). It has the ability to generate over $10^{8}$ copies of the desired nucleic acid sequence within 30 min (Wernecke and Mullen, 2014) and amplicons are detected via a probe-capture hybridization using electrochemiluminescence in molecular beacons (Heo et al., 2019). NASBA does not require a thermal cycler and the amplification power is comparable or better than real-time based PCR assays (Loens et al., 2006). Moreover, NASBA requires only short reactions, has high sensitivity and stringent control, and is not affected by inhibitors and is well suited for lab-on-a-chip devices (Honsvall and Robertson, 2017). The application is very rare in plant fungal pathogen detection. However, it has potential to be used in the detection of fungal diseases in future.

\section{Post Amplification Techniques DNA Microarray}

A DNA microarray (DNA chip, gene chip, or biochip) (Bhatia and Dahiya, 2015) is an assemblage of microscopic DNA spots attached to a solid surface (usually glass) in defined positions. The microscopic spots consist of thousands of specific DNA sequences (probes) that are used to hybridize a cDNA (target) sample. Hybridized probecDNA systems can be detected and quantified using fluorophore, silver, or chemiluminescence-labeled targets to define the comparative abundance of transcripts in the sample (Guigó, 2013). Advancement of DNA microarray technology has led high throughput and multiple detection of various phytopathogens including viruses, viroids, bacteria, and fungi (Tiberini and Barba, 2012; Musser et al., 2014; Nam et al., 2014; Krawczyk et al., 2017). PCR primers and florescent probes for targeting fungal potato pathogens Rhizoctonia solani, Spongospora subterranea (ITS region), Alternaria solani, A. alternata (Alt_al gene), Fusarium sp. (TEF-1 $\alpha$ ), and Colletotrichum coccodes (TUB2) were used with qPCR microarray technology in 48-well silicon microarrays (Nikitin et al., 2018). A novel microarray assay (ArrayTube) using marker genes ITS, TEF- $1 \alpha$, and $16 S$ rDNA with well performing probes allowed the detection of various sugar beet root rot pathogens, Aphanomyces cochlioides, Botrytis cinerea, and Penicillium expansum (Liebe et al., 2016). DNA microarrays can be produced batch wise on standard microscope slides in a rapid, easy, consistent, and cost-efficient way (Johannes et al., 2020). A major drawback of microarray is that it can only detect sequences that the array is designed to identify (Bumgarner, 2013).

\section{DNA Macroarray}

DNA macroarrays are built by designing species-specific probes (15-30 bases of oligonucleotides) that are arrayed into well plates and fixed on a nylon or nitrocellulose membrane. The probe hybridization with PCR amplified and labeled target DNA sequence can then be detected (Clark et al., 1999; Zhang et al., 2008). An oligo-DNA macroarray assay was established with digoxigenin-labeled RNA probes to identify the microbes in the phyllosphere of apple trees (He et al., 2012). For the identification of fungi, $40 \mathrm{bp}$ of oligo-DNA sequences were selected from the fungal $r D N A-I T S$ region and fungal pathogens that inflict scab (Venturia inaequalis), Alternaria blotch (Alternaria mali), and Marssonina blotch (Diplocarpon mali) were detected along with several nonphytopathogenic fungal and bacteria (He et al., 2012). DNA macroarray based reverse-blot hybridization was performed to target the TUB2 gene from isolated DNA and amplified using $\mathrm{Bt} 2 \mathrm{a}$ and $\mathrm{Bt} 2 \mathrm{~b}$ primers that were labelled with digoxygenin in PCR. This array endorsed the detection and discrimination of 15 different species belonging to the genera Cadophora, Campylocarpon, Cylindrocarpon, Dactylonectria, Ilyonectria, Neonectria, and Phaeomoniella including the black-foot pathogens Campylocarpon fasciculare, C. pseudofasciculare, Dactylonectria macrodidyma, D. pauciseptata, Ilyonectria europaea, I. liriodendri, and I. robusta (Agustí-Brisach and Armengol, 2013). Young vine decline (YVD) is a complex disease in grapevine that causes severe mortality in young vineyards (Úrbez-Torres et al., 2015). Sixty-one species including 34 YVD fungal pathogens were diagnosed by a DNA macroarray (Úrbez-Torres et al., 2015). Macroarray offers a reliable and effective method for pathogen diagnosis even if the sample contains multiple pathogens (Zhang et al., 2008). Finite life of filters, annotations of potential new genes showing low abundance of transcripts, and large volume of filters needed to be hybridized are major limitations of macroarray (Gammill and Lee, 2008). The other pitfalls of this array are lack of pathogen quantification and the impossibility to define whether the detected DNA is from a live organism (ÚrbezTorres et al., 2015).

\section{DNA or RNA Probe Based Assays In Situ Hybridization}

In situ hybridization (ISH) technique functions to detect mRNAs present in the fixed sample. Designing of an antisense ssRNA probe aimed to bind target mRNA (sequence of interest) is the main step of this assay. However, synthetic oligonucleotide probes and cDNA probes can also be used (Jensen, 2014). Typically, probes are labeled with the radioactive isotopes ${ }^{35} \mathrm{~S}$, ${ }^{125} \mathrm{I}$, and ${ }^{32} \mathrm{P}$ for probe labeling as they are very sensitive and easily quantified for detection. Nonisotopic probes can use biotin, digoxigenin, tyramide, alkaline phosphatase, or bromodeoxyuridine for probe labeling. Photography, autoradiography with X-ray film, liquid emulsion, and microscopic techniques can be used in signal detection (Corthell, 2014). The rust fungi Puccinia horiana isolate PA-11, Uromyces transversalis isolate CA-07, and Phakopsora pachyrhizi isolate Taiwan 72-1 infecting Chrysanthemum $\times$ morifolium, Gladiolus $\times$ hortulanus, and Glycine max respectively, were distinguished as rust pathogens in their respective paraffin fixed plant tissues using the ISH technique (Ellison et al., 2016). ISH 
enables maximum usage of tissue that is hard to obtain, but the main limitations of ISH are cost and hazardous nature of radioactive probes, and the difficulty in identification when the target has low concentrations of DNA and RNA (Jin and Lloyd, 1997).

\section{Fluorescent In Situ Hybridization}

Fluorescent in situ hybridization (FISH) is a comparatively recent and innovative technology in plant disease diagnostics. It combines the specificity in DNA sequences with the sensitivity of detection systems based on fluorochromes (Hijri, 2009; Cui et al., 2016). FISH assays include the detection of DNA or RNA sequences in cells or tissues using DNA or RNA probes, which are labeled directly or indirectly with fluorochromes (Shakoori, 2017). In normal FISH methods, fluorescently mono-labeled oligonucleotide probes are hybridized to the ribosomal RNA (rRNA) of microbial cells, and the stained cells are then visualized by wide field epifluorescence or confocal laser scanning microscopy (Lukumbuzya et al., 2019). Upon pathogen infection, pathogen-specific rRNA sequences will be present in plants. This specific information provided by RNA can be detected by FISH (Fang and Ramasamy, 2015). Southern blight in tomato is caused by a soil-borne pathogen, Sclerotium rolfsii. Soil smears in a DNA isolation with $0.06 \mathrm{pg} \mu^{-1}$ of $S$. rolfsii was effectively detected by FISH technique that used an oligonucleotide probe labeled with cyanine dyes Cy3 and Cy5 (Milner et al., 2019). Reproducibility, sensitivity, specificity, accuracy, and speed are the best features of FISH (Bozorg-Ghalati et al., 2019). It also has potential to deliver information about resolution, morphology, and identification of main pathogens in mixed species specimens (Frickmann et al., 2017). False positive results with autofluorescence materials are a common pitfall that reduces specificity during the assay (Moter and Göbel, 2000).

\section{Next-Generation Sequencing}

Next-generation sequencing (NGS) or high throughput sequencing (HTS) is a new approach for diagnostics. The development of NGS technologies has fueled innovative ways for detection and identification of phytopathogens (Chalupowicz et al., 2019). Isolation and fragmentation of DNA, library preparation, massive parallel sequencing, bioinformatics analysis, and variant/mutation annotation and interpretation are the major steps involved in DNA based NGS (Qin, 2019). Massively parallel signature sequencing, pyrosequencing, polony sequencing, and sequencing by oligonucleotide ligation detection (SOLID) are some commonly available advanced sequencing methods in HTS (Rajesh and Jaya, 2017). RNA-Sequencing (RNA-Seq) offers advanced coverage and greater resolution of the dynamic nature of the transcriptome. The Illumina HiSeq platform is the most universally functional NGS platform for RNA-Seq and has established the standard for NGS. The platform more recently released a desktop sequencer, MiSeq (Kukurba and Montgomery, 2015).

RNA-Seq based NGS can be used in the rapid identification of fungal plant pathogens inducing novel diseases. A whole-genome sequencing approach using Illumina MiSeq was established to detect the Sarcococca blight-causing novel fungal pathogen, Calonectria pseudonaviculata in ornamental plants. A $51.4 \mathrm{Mb}$ genome of the two host isolates showed a unique single nucleotide polymorphism for the two isolates and identified both as C. pseudonaviculata (Malapi-Wight et al., 2016b). Datasets from population genomics built on NGS can be exploited to recuperate variations including single nucleotide polymorphisms (SNPs), insertions and deletions (INDELS), and structural variations (Potgieter et al., 2020). Puccinia striiformis $\mathrm{f}$. sp. tritici (PST) is an emerging or re-emerging plant infecting fungus that causes wheat yellow (stripe) rust in wheat and triticale. Field pathogenomics was done using RNA-Seq based NGS of PST infested wheat leaves to gain insight into emergent pathogen populations. The results revealed that there was a dramatic shift in the PST population in the UK, likely due to a current introduction of a different set of emerging and exotic PST lineages (Hubbard et al., 2015). RNA and DNA based NGS approach was conducted to develop molecular diagnostics for the cucurbit downy mildew pathogen Pseudoperonospora cubensis. Comparative genomics using RNA-Seq of close relative species $P$. humuli identified seven specific regions in $P$. cubensis that allowed for the development of diagnostic markers (Withers et al., 2016).

Monilinia fructicola, a brown rot disease causing fungal pathogen, causes post- and pre-harvest damages in stone and pome fruits. A hybrid and hierarchical de novo association strategy was used to sequence the genome of $M$. fructicola Mfrc123 strain through an amalgamation of Illumina short read NGS and Pacific Biosciences (PacBio) long read third-generation sequencing platforms (Angelini et al., 2019). In another hybrid approach, the genome of the coffee rust fungus Hemileia vastarix was sequenced using PacBio RS II and Illumina HiSeq platforms and a total genome of $547 \mathrm{Mb}$ of $H$. vastatrix race XXXIII was generated (Porto et al., 2019). The sequenced reference genomes can be used to study the genome biology and evolution with other species. The arrival of a novel pathogen is an instance where the target cannot be well-defined. Since NGS involves no prior knowledge of pathogen sequences, the whole genome of the causal organism may be sequenced without using specific primer pairs and PCR amplification (Hadidi et al., 2016; Malapi-Wight et al., 2016b). Among NGS approaches, advances in single-molecule sequencing technologies, "third-generation sequencing," has advantages over second-generation sequencing techniques (Schadt et al., 2010). The major limitation in NGS is the time consumption incurred during assembly and analysis of large amounts of sequence data (Espindola et al., 2015). Next generation applications are often restricted by low RNA yield and/or integrity, RNA stability, and impurities with DNA, salts, or chemicals (Cortés-Maldonado et al., 2020). Also, bioinformatics and mycological expertise are necessary for NGS analysis, even if the data can be easily and quickly obtained, so that knowledge about fungal and bioinformatics analyses are mandatory to avoid any misinterpretation.

\section{CONCLUSION}

Recent advances in molecular biological techniques have increased detection and diagnosis of novel, emerging, previously reported, and re-emerging fungal plant pathogens. Traditional and variant 
polymerase chain reaction (PCR) based assays, isothermal and post amplification tools, hybridization techniques, and next-generation sequencing (NGS) approaches are well-known for diagnostics in phytofungal disease detection. These molecular-based approaches have successfully identified and diagnosed symptomatic and asymptomatic diseases of culturable and unculturable fungal pathogens in sole and co-infections of agriculturally important field, horticultural, floricultural, ornamental, and forest plant species. Among various PCR centered assays, quantitative PCR has been extensively used in the quantification and differentiation of causal agents when the sample load is too insignificant to detect. Currently, loop-mediated amplification (LAMP) is showing success in the fungal disease detection arena and has facilitated identification of Alternaria spp., Colletotrichum spp., Fusarium spp., Verticillium spp., Puccinia spp., Botrytis spp., etc. that cause an array of devastating diseases in plants. NGS uses various platforms to sequence fungal genomes with no prior knowledge of the pathogen's sequence, and can be used to identify novel and emerging pathogens.

\section{REFERENCES}

Abdullah, A. S., Turo, C., Moffat, C. S., Lopez-Ruiz, F. J., Gibberd, M. R., Hamblin, J., et al. (2018). Real-time PCR for diagnosing and quantifying co-infection by two globally distributed fungal pathogens of wheat. Front. Plant Sci. 9, 1086. doi: $10.3389 /$ fpls.2018.01086

Agrios, G. N. (2009). Plant pathogens and disease: General introduction (University of Florida, Gainesville, FL USA: Elsevier Inc). doi: 10.1016/B978012373944-5.00344-8

Agustí-Brisach, C., and Armengol, J. (2013). Black-foot disease of grapevine: An update on taxonomy, epidemiology and management strategies. Phytopathol. Mediterr. 52, 245-261.

Alemu, K. (2014). Real-time PCR and its application in plant disease diagnostics. Adv. Life Sci. Technol. 27, 39-49.

Almasi, M. A. (2019). Development of a colorimetric loop-mediated isothermal amplification assay for the visual detection of Fusarium oxysporum f. sp. melonis. Hortic. Plant J. 5 (3), 129-136. doi: 10.1016/j.hpj.2019.01.004

Amagliani, G., Omiccioli, E., Campo, A., Bruce, I. J., Brandi, G., and Magnani, M. (2006). Development of a magnetic capture hybridization-PCR assay for Listeria monocytogenes direct detection in milk samples. J. Appl. Microbiol. 100, 375-383. doi: 10.1111/j.1365-2672.2005.02761.x

Angelini, R. M. D. M., Romanazzi, G., Pollastro, S., Rotolo, C., Faretra, F., and Landi, L. (2019). New high-quality draft genome of the brown rot fungal pathogen Monilinia fructicola. Genome Biol. Evol. 11 (10), 2850-2855. doi: 10.1093/gbe/evz207

Asibi, A. E., Chai, Q., and Coulter, J. A. (2019). Rice Blast: A disease with implications for global food security. Agronomy 9, 451. doi: 10.3390/ agronomy9080451

Aslam, S., Tahir, A., Aslam, M. F., Alam, M. W., Shedayi, A. A., and Sadia, S. (2017). Recent advances in molecular techniques for the identification of phytopathogenic fungi - a mini review. J. Plant Interact. 12 (1), 493-504. doi: 10.1080/17429145.2017.1397205

Ayukawa, Y., Hanyuda, S., Fujita, N., Komatsu, K., and Arie, T. (2017). Novel loop-mediated isothermal amplification (LAMP) assay with a universal QProbe can detect SNPs determining races in plant pathogenic fungi. Sci. Rep. 7, 4253. doi: 10.1038/s41598-017-04084-y

Badali, H., and Nabili, M. (2012). Molecular tools in medical mycology; where we are! Jundishapur J. Microbiol. 6 (1), 1-3. doi: 10.5812/jjm.8566

Balodi, R., Bisht, S., Ghatak, A., and Rao, K. H. (2017). Plant disease diagnosis: technological advancements and challenges. Indian Phytopathol. 70 (3), 275281. doi: 10.24838/ip.2017.v70.i3.72487

Becherer, L., Borst, N., Bakheit, M., Frischmann, S., Zengerle, R, and von Stetten, F. (2020). Loop-mediated isothermal amplification (LAMP) - review and
The molecular methods covered in this review are accurate, effective, lab-oriented, and require sophisticated instruments to identify fungal plant pathogens. However, expertise in mycology and bioinformatics are essential to avoid any misinterpretation of the results obtained from the molecular biological analyses. Molecular techniques should become a point of care testing (POCT) by combining with other emergent technological advancements for fungal disease diagnosis. The challenges are with scientists to develop practical approaches for molecular diagnostics of crop diseases.

\section{AUTHOR CONTRIBUTIONS}

GH gathered literature and wrote the manuscript with input from KP. KP conceived the idea and provided guidance throughout and involved in critical revisions. All authors contributed to the article and approved the submitted version.

classification of methods for sequence-specific detection. Anal. Methods 12 (6), 717-746. doi: 10.1039/C9AY02246E

Bhat, R. G., and Browne, G. T. (2010). Specific detection of Phytophthora cactorum in diseased strawberry plants using nested polymerase chain reaction. Plant Pathol. 59, 121-129. doi: 10.1111/j.1365-3059.2009.02147.x

Bhat, A. I., and Rao, G. P. (2020). "Rolling circle amplification (RCA)," in Characterization of Plant Viruses - Methods and Protocols (Humana, New York: Springer), 377-382. doi: 10.1007/978-1-0716-0334-5_39

Bhatia, S., and Dahiya, R. (2015). "Concepts and techniques of plant tissue culture science," in Modern Applications of Plant Biotechnology in Pharmaceutical Sciences. Eds. S. Bhatia, K. Sharma, R. Dahiya and T. Bera (Boston: Academic Press), 121-156. doi: 10.1016/B978-0-12-802221-4.00004-2

Bilska, K., Kulik, T., Ostrowska-Kołodziejczak, A., Busko, M., Pasquali, M., Beyer, M., et al. (2018). Development of a highly sensitive FcMito qPCR assay for the quantification of the toxigenic fungal plant pathogen Fusarium culmorum. Toxins 10 (5), 211. doi: 10.3390/toxins 10050211

Bozorg-Ghalati, F., Mohammadpour, I., and Ranjbaran, R. (2019). Applications of fluorescence in situ hybridization in detection of disease biomarkers and personalized medicine. Comp. Clin. Pathol. 28, 3-10. doi: 10.1007/s00580017-2625-x

Brewer, M. T., Turner, A. N., Brannen, P. M., Cline, W. O., and Richardson, E. A. (2014). Exobasidium maculosum, a new species causing leaf and fruit spots on blueberry in the southeastern USA and its relationship with other Exobasidium spp. parasitic to blueberry and cranberry. Mycologia 106 (3), 415-423. doi: 10.3852/13-202

Bumgarner, R. (2013). Overview of DNA microarrays: types, applications, and their future. Curr. Protoc. Mol. Biol. 101, 22.1.1-22.1.11. doi: 10.1002/ 0471142727.mb2201s101

Caetano-Anolles, D. (2013). "Polymerase Chain Reaction," in Brenner's Encyclopedia of Genetics. Eds. S. Maloy and K. Hughes (San Diego: Academic Press), 392-395. doi: 10.1016/B978-0-12-374984-0.01186-4

Capote, N., Mara, A., Aguado, A., and Snchez-Torres, P. (2012). "Molecular tools for detection of plant pathogenic fungi and fungicide resistance," in Plant Pathology. Ed. C. J. R. Cumagun (RI, USA: InTech), 151-202. doi: 10.5772/38011

Carnielli-Queiroz, L., Fernandes, P. M. B., Fernandes, A. A. R., and Ventura, J. A. (2019). A rapid and reliable method for molecular detection of Fusarium guttiforme, the Etiological Agent of Pineapple Fusariosis. Braz. Arch. Biol. Technol. 62, e19180591. doi: 10.1590/1678-4324-2019180591

Cenis, J. L. (1992). Rapid extraction of fungal DNA for PCR amplification. Nucleic Acids Res. 20, 2380. doi: 10.1093/nar/20.9.2380

Chalupowicz, L., Dombrovsky, A., Gaba, V., Luria, N., Reuven, M., Beerman, A., et al. (2019). Diagnosis of plant diseases using the Nanopore sequencing platform. Plant Pathol. 68, 229-238. doi: 10.1111/ppa.12957 
Chandelier, A., Massot, M., Fabreguettes, O., Gischer, F., Teng, F., and Robin, C. (2019). Early detection of Cryphonectria parasitica by real-time PCR. Eur. J. Plant Pathol. 153, 29-46. doi: 10.1007/s10658-018-1538-0

Chander, Y., Koelbl, J., Puckett, J., Moser, M. J., Klingele, A. J., Liles, M. R., et al. (2014). A novel thermostable polymerase for RNA and DNA loop-mediated isothermal amplification (LAMP). Front. Microbiol. 5, 395. doi: 10.3389/ fmicb.2014.00395

Chandra, A., Keizerweerd, A. T., Que, Y., and Grisham, M. P. (2015). Loopmediated isothermal amplification (LAMP) based detection of Colletotrichum falcatum causing red rot in sugarcane. Mol. Biol. Rep. 42 (8), 1309-1316. doi: 10.1007/s11033-015-3875-9

Chang, C. C., Chen, C. C., Wei, S. C., Lu, H. H., Liang, Y. H., and Lin, C. W. (2012). Diagnostic devices for isothermal nucleic acid amplification. Sensors (Basel Switzerland) 12 (6), 8319-8337. doi: 10.3390/s120608319

Chen, J., and Griffiths, M. W. (2001). "Magnetic capture hybridization polymerase chain reaction," in Food Microbiology Protocols. Methods in Biotechnology, vol. vol 14. Eds. J. F. T. Spencer and A. L. de Ragout Spencer (Totowa, NJ: Humana Press), 107-110. doi: 10.1385/1-59259-029-2:107

Cheng, Y., Tang, X., Gao, C., Li, Z., Chen, J., Guo, L., et al. (2020). Molecular Diagnostics and Pathogenesis of Fungal Pathogens on Bast Fiber Crops. Pathogens 9 (3), 223. doi: 10.3390/pathogens 9030223

Chi, M., Park, S., and Lee, Y. (2009). A quick and safe method for fungal DNA extraction. Plant Pathol. J. 25, 108-111. doi: 10.5423/PPJ.2009.25.1.108

Cho, H. J., Hong, S. W., Kim, H. J., and Kwak, Y. S. (2016). Development of a multiplex PCR method to detect fungal pathogens for quarantine on exported cacti. Plant Pathol. J. 32 (1), 53-57. doi: 10.5423/PPJ.NT.09.2015.0184

Clark, M., Panopoulou, G., Cahill, D., Büssow, K., and Lehrach, H. (1999). Construction and analysis of arrayed cDNA libraries. Meth. Enzymol. 303, 205-233. doi: 10.1016/S0076-6879(99)03015-3

Conti, M., Cinget, B., Vivancos, J., Oudemans, P., and Bélanger, R. R. (2019). A molecular assay allows the simultaneous detection of 12 fungi causing fruit rot in Cranberry. Plant Dis. 103 (11), 2843-2850. doi: 10.1094/PDIS-03-19-0531-RE

Cortés-Maldonado, L., Marcial-Quino, J., Gómez-Manzo, S., Fierro, F., and Tomasini, A. (2020). A method for the extraction of high quality fungal RNA suitable for RNA-seq. J. Microbiol. Methods 170, 105855. doi: 10.1016/ j.mimet.2020.105855

Corthell, J. T. (2014). "In Situ Hybridization," in Basic Molecular Protocols in Neuroscience: Tips, Tricks, and Pitfalls (San Diego: Academic Press), 105-111. doi: 10.1016/B978-0-12-801461-5.00011-3

Cui, C., Shu, W., and Li, P. (2016). Fluorescence in situ hybridization: Cell-based genetic diagnostic and research applications. Front. Cell Dev. Biol. 4:89:89. doi: 10.3389/fcell.2016.00089

Dai, T., Lu, C., Lu, J., Dong, S., Ye, W., Wang, Y., et al. (2012). Development of a loopmediated isothermal amplification assay for detection of Phytophthora sojae. FEMS Microbiol. Lett. 334 (1), 27-34. doi: 10.1111/j.1574-6968.2012.02619.x

Darras, A. I. (2016). "Postharvest disease management," in Handbook of Florists' Crops Diseases. Eds. R. McGovern and W. Elmer (Cham: Springer). doi: 10.1007/978-3-319-32374-9_11-1

Davari, M., van Diepeningen, A. D., Babai-Ahari, A., Arzanlou, M., Najafzadeh, M. J., van der Lee, T. A., et al. (2012). Rapid identification of Fusarium graminearum species using Rolling circle amplification (RCA). J. Microbiol. Methods 89 (1), 63-70. doi: 10.1016/j.mimet.2012.01.017

Depotter, J. R. L., Rodriguez-Moreno, L., Thomma, B. P. H. A., and Wood, T. A. (2017). The Emerging British Verticillium longisporum Population Consists of Aggressive Brassica Pathogens. Phytopathology 107 (11), 1399-1405. doi: 10.1094/PHYTO-05-17-0184-R

Doehlemann, G., Ökmen, B., Zhu, W., and Sharon, A. (2017). Plant Pathogenic Fungi. Microbiol. Spectr. 5 (1), FUNK-0023-2016. doi: 10.1128/microbiolspec.FUNK0023-2016

Dong, H., Wang, C., Xiong, Y., Lu, H., Ju, H., and Zhang, X. (2013). Highly sensitive and selective chemiluminescent imaging for DNA detection by ligation-mediated rolling circle amplified synthesis of DNAzyme. Biosens. Bioelectron. 41, 348-353. doi: 10.1016/j.bios.2012.08.050

Doyle, V. P., Tonry, H. T., Amsden, B., Beale, J., Dixon, E., Li, H., et al. (2019). First report of Cercospora cf. flagellaris on industrial hemp (Cannabis saliva) in Kentucky. Plant Dis. 103, 1784. doi: 10.1094/PDIS-01-19-0135-PDN

Doyle, J. (1991). "DNA Protocols for Plants," in Molecular Techniques in Taxonomy. NATO ASI Series (Series H: Cell Biology), vol. 57. Eds. G. M.
Hewitt, A. W. B. Johnston and J. P. W. Young (Berlin, Heidelberg: Springer), 283-293. doi: 10.1007/978-3-642-83962-7_18

Duan, Y., Ge, C., Zhang, X., Wang, J., and Zhou, M. (2014). A rapid detection method for the plant pathogen Sclerotinia sclerotiorum based on loopmediated isothermal amplification (LAMP). Australas. Plant Path. 43, 61-66. doi: 10.1007/s13313-013-0239-6

Duan, Y. B., Ge, C. Y., Zhang, X. K., Wang, J. X., and Zhou, M. G. (2014). Development and evaluation of a novel and rapid detection assay for Botrytis cinerea based on loop-mediated isothermal amplification. PLoS One 9 (10), e111094. doi: 10.1371/journal.pone.0111094

Ellison, M. A., McMahon, M. B., Bonde, M. R., Palmer, C. L., and Luster, D. G. (2016). In situ hybridization for the detection of rust fungi in paraffin embedded plant tissue sections. Plant Methods 12, 37. doi: 10.1186/s13007016-0137-3

Elverson, T. R., Kontz, B. J., Markell, S. G., Harveson, R. M., and Mathew, F. M. (2020). Quantitative PCR Assays Developed for Diaporthe helianthi and Diaporthe gulyae for Phomopsis Stem Canker Diagnosis and Germplasm Screening in Sunflower (Helianthus annuus). Plant Dis. 104 (3), 793-800. doi: 10.1094/PDIS-09-19-1827-RE

Espindola, A., Schneider, W., Hoyt, P. R., Marek, S. M., and Garzon, C. (2015). A new approach for detecting fungal and oomycete plant pathogens in next generation sequencing metagenome data utilizing electronic probes. Int. J. Data Min. Bioinform. 12, 115-128. doi: 10.1504/IJDMB.2015.069422

Faganello, F. D. S., Filho, R. C., Dias, V. D., Morello, R. M. S. C., and Da Cunha, M. G. (2017). Molecular diagnosis of Guignardia citricarpa in asymptomatic sweet orange tissue. Rev. Bras. Frutic. 39 (4), e-518. doi: 10.1590/0100-29452017518

Fang, Y., and Ramasamy, R. P. (2015). Current and prospective methods for plant disease detection. Biosensors 5, 537-561. doi: 10.3390/bios5030537

FAO, IFAD, UNICEF, WFP and WHO (2018). The State of food security and nutrition in the world 2018. Building Climate Resilience for Food Security and Nutrition (Rome: FAO).

Faria, C. B., Abe, C. A., da Silva, C. N., Tessmann, D. J., and Barbosa-Tessmann, I. P. (2012). New PCR assays for the identification of Fusarium verticillioides, Fusarium subglutinans, and other species of the Gibberella fujikuroi complex. Int. J. Mol. Sci. 13 (1), 115-132. doi: 10.3390/ijms13010115

Fatmi, M., Damsteegt, V. D., and Schaad, N. W. (2005). A combined agar-absorption and BIO-PCR assay for rapid, sensitive detection of Xylella fastidiosa in grape and citrus. Plant Pathol. 54, 1-7. doi: 10.1111/j.1365-3059.2005.01114.x

Fisher, M. C., Gurr, S. J., Cuomo, C. A., Blehert, D. S., Jin, H., Stukenbrock, E. H., et al. (2020). Threats Posed by the Fungal Kingdom to Humans, Wildlife, and Agriculture. mBio 11 (3), e00449-e00420. doi: 10.1128/mBio.00449-20

Francois, P., Tangomo, M., Hibbs, J., Bonetti, E. J., Boehme, C. C., Notomi, T., et al. (2011). Robustness of a loop-mediated isothermal amplification reaction for diagnostic applications. FEMS Immunol. Med. Microbiol. 62, 41-48. doi: 10.1111/j.1574-695X.2011.00785.x

Frickmann, H., Zautner, A. E., Moter, A., Kikhney, J., Hagen, R. M., Stender, H., et al. (2017). Fluorescence in situ hybridization (FISH) in the microbiological diagnostic routine laboratory: a review. Crit. Rev. Microbiol. 43 (3), 263-293. doi: 10.3109/1040841X.2016.1169990

Gammill, L. S., and Lee, V. M. (2008). Gene discovery: macroarrays and microarrays. Methods Cell Biol. 87, 297-312. doi: 10.1016/S0091-679X(08)00216-1

Gao, H., Zhang, K., Teng, X., and Li, J. (2019). Rolling circling amplification for a single cell analysis and in situ sequencing. Trends Anal. Chem. 121, 115700. doi: 10.1016/j.trac.2019.115700

Garrido, C., Carbu, M., Acreo, F. J., Boonham, N., Coyler, A., Cantoral, J. M., et al. (2009). Development of protocols for detection of Colletotrichum acutatum and monitoring of strawberry anthracnose using real-time PCR. Plant Pathol. 58, 43-51. doi: 10.1111/j.1365-3059.2008.01933.x

Ghosh, R., Nagavardhini, A., Sengupta, A., and Sharma, M. (2015). Development of loop-mediated isothermal amplification (LAMP) assay for rapid detection of Fusarium oxysporum f. sp. ciceris - wilt pathogen of chickpea. BMC Res. Notes 8, 40. doi: 10.1186/s13104-015-0997-z

Godfray, H. C., Mason-D'Croz, D., and Robinson, S. (2016). Food system consequences of a fungal disease epidemic in a major crop. Philos. Trans. $R$. Soc. Lond. Ser. B Biol. Sci. 371 (1709), 20150467. doi: 10.1098/rstb.2015.0467

Gontia-Mishra, I., Tripathi, N., and Tiwari, S. (2014). A simple and rapid DNA extraction protocol for filamentous fungi efficient for molecular studies. Indian J. Biotechnol. 13, 536-539. 
Goo, N., and Kim, D. (2016). Rolling circle amplification as isothermal gene amplification in molecular diagnostics. Biochip J. 10, 262-271. doi: 10.1007/ s13206-016-0402-6

Griffiths, M. W. (2014). "Nucleic acid-based assays: Overview," in Encyclopedia of Food Microbiology. Eds. C. A. Batt and M. L. Tortorello (Oxford: Academic Press), 990-998. doi: 10.1016/B978-0-12-384730-0.00243-3

Gu, L., Yan, W., Liu, L., Wang, S., Zhang, X., and Lyu, M. (2018). Research progress on rolling circle amplification (RCA)-based biomedical sensing. Pharmaceuticals (Basel Switzerland) 11 (2), 35. doi: 10.3390/ph11020035

Guan, X. Y., Guo, J. C., Shen, P., Yang, L. T., and Zhang, D. B. (2010). Visual and rapid detection of two genetically modified soybean events using loopmediated isothermal amplification method. Food Anal. Methods 3, 313-320. doi: $10.1007 / \mathrm{s} 12161-010-9132-\mathrm{x}$

Guigó, R. (2013). "The coding and the non-coding transcriptome," in Handbook of Systems Biology. Eds. A. J. M. Walhout, M. Vidal and J. Dekker (San Diego: Academic Press), 27-41. doi: 10.1016/B978-0-12-385944-0.00002-2

Ha, Y., Fessehaie, A., Ling, K. S., Wechter, W. P., Keinath, A. P., and Walcott, R. R. (2009). Simultaneous detection of Acidovorax avenae subsp. citrulli and Didymella bryoniae in cucurbit seedlots using magnetic capture hybridization and real-time polymerase chain reaction. Phytopathology 99 (6), 666-678. doi: 10.1094/PHYTO-99-6-0666

Hadidi, A., Flores, R., Candresse, T., and Barba, M. (2016). Next-generation sequencing and genome editing in plant virology. Front. Microbiol. 7, 1325. doi: $10.3389 /$ fmicb.2016.01325

Havis, N. D., Gorniak, K., Carmona, M. A., Formento, A. N., Luque, A. G., and Scandiani, M. M. (2014). First molecular detection of Ramularia leaf spot (Ramularia collo-cygni) in seeds and leaves of barley in Argentina. Plant Dis. 98 (2), 277-277. doi: 10.1094/PDIS-04-13-0416-PDN

Havis, N. D., Brown, J. K. M., Clemente, G., Frei, P., Jedryczka, M., Kaczmarek, J., et al. (2015). Ramularia collo-cygni - An emerging pathogen of barley crops. Phytopathology 105 (7), 895-904. doi: 10.1094/PHYTO-11-14-0337-FI

He, Y. H., Isono, S., Shibuya, M., Tsuji, M., Adkar Purushothama, C. R., Tanaka, K., et al. (2012). Oligo-DNA custom macroarray for monitoring major pathogenic and non-pathogenic fungi and bacteria in the phyllosphere of apple trees. PLoS One 7 (3), e34249. doi: 10.1371/journal.pone.0034249

Heo, S., Kim, H. R., and Lee, H. J. (2019). Development of a quantitative real-time nucleic acid sequence based amplification (NASBA) assay for early detection of apple scar skin viroid. Plant Pathol. J. 35 (2), 164-171. doi: 10.5423/ PPJ.OA.10.2018.0206

Hijri, M. (2009). The use of fluorescent in situ hybridization in plant fungal identification and genotyping. Methods Mol. Biol. 508, 131-145. doi: 10.1007/ 978-1-59745-062-1_11

Honsvall, B. K., and Robertson, L. J. (2017). From research to lab to standard environmental analysis tool. Will NASBA make keep? Water Res. 109, 389397. doi: $10.1016 /$ j.watres.2016.11.052

Horst, R. (2008). "Classification of plant pathogens," in Westcott's Plant Disease Handbook. Ed. R. Horst (Dordrecht: Springer), 43-79. doi: 10.1007/978-14020-4585-1_2

Hubbard, A., Lewis, C. M., Yoshida, K., Ramirez-Gonzalez, R. H., de VallavieillePope, C., Thomas, J., et al. (2015). Field pathogenomics reveals the emergence of a diverse wheat yellow rust population. Genome Biol. 16 (1), 23. doi: 10.1186/ s13059-015-0590-8

Hussain, F., and Usman, F. (2019). "Fungal biotic stresses in plants and its control strategy," in Abiotic and biotic stress in plants. Ed. A. B. de Oliveira (London: IntechOpen). doi: 10.5772/intechopen.83406

Ippolito, A., Schena, L., and Nigro, F. (2002). Detection of Phytophthora nicotiane and P. citrophthora in citrus roots and soils by nested PCR. Eur. J. Plant Pathol. 108, 855-868. doi: 10.1023/A:1021208106857

Iqbal, Z., Khan, M. A., Sharif, M., Shah, J. H., Rehman, M. H., and Javed, K. (2018). An automated detection and classification of citrus plant diseases using image processing techniques: A review. Comput. Electron. Agric. 153, 12-32. doi: 10.1016/j.compag.2018.07.032

Jacobsen, C. S. (1995). Microscale detection of specific bacterial DNA in soil with a magnetic capture-hybridization and PCR amplification assay. Appl. Environ. Microbiol. 61, 3347-3352. doi: 10.1128/AEM.61.9.3347-3352.1995

Jain, A., Sarsaiya, S., Wu, Q., Lu, Y., and Shi, J. (2019). A review of plant leaf fungal diseases and its environment speciation. Bioengineered 10 (1), 409-424. doi: $10.1080 / 21655979.2019 .1649520$
Jensen, E. (2014). Technical Review: In Situ Hybridization. Anat. Rec. 297 (8), 1349-1353. doi: 10.1002/ar.22944

Jin, L., and Lloyd, R. V. (1997). In situ hybridization: methods and applications. J. Clin. Lab. Anal. 11 (1), 2-9. doi: 10.1002/(SICI)1098-2825(1997)11:1<2:: AID-JCLA2>3.0.CO;2-F

Johannes, W., Stefan, D. K., Philipp, A. M., Christin, R., Matthias, H., Gerald, A. U., et al. (2020). Digital DNA microarray generation on glass substrates. Sci. Rep. 10, 5770. doi: 10.1038/s41598-020-62404-1

Johnson, K. L., Zheng, D., Kaewnum, S., Reid, C. L., and Burr, T. (2013). Development of a magnetic capture hybridization real-time PCR assay for detection of tumorigenic Agrobacterium vitis in grapevines. Phytopathology 103, 633-640. doi: 10.1094/PHYTO-10-12-0267-R

Johnston-Monje, D., and Mejia, J. L. (2020). Botanical microbiomes on the cheap: Inexpensive molecular fingerprinting methods to study plant-associated communities of bacteria and fungi. Appl. Plant Sci. 8, e11334. doi: 10.1002/ aps3.11334

Kaczmarek, A. M., King, K. M., West, J. S., Stevens, M., Sparkes, D., and Dickinson, M. (2019). A loop-mediated isothermal amplification (LAMP) assay for rapid and specific detection of airborne inoculum of Uromyces betae (sugar beet rust). Plant Dis. 103 (3), 417-421. doi: 10.1094/PDIS-0218-0337-RE

Kieser, R. E., and Budowle, B. (2020). Rolling circle amplification: A (random) primer on the enrichment of an infinite linear DNA template. WIREs Forensic Sci. 2, e1359. doi: 10.1002/wfs2.1359

King, K. M., Krivova, V., Canning, G. G. M., Hawkins, N. J., Kaczmarek, A. M., Perryman, S. A. M., et al. (2018). Loop-mediated isothermal amplification (LAMP) assays for rapid detection of Pyrenopeziza brassicae (light leaf spot of brassicas). Plant Pathol. 67, 167-174. doi: 10.1111/ppa.12717

Kong, X., Qin, W., Huang, X., Kong, F., Schoen, C. D., Feng, J., et al. (2016) Development and application of loop-mediated isothermal amplification (LAMP) for detection of Plasmopara viticola. Sci. Rep. 6, 28935. doi: $10.1038 /$ srep 28935

Kong, L., Wang, H., Wang, S., Xu, P., Zhang, R., Dong, S., et al. (2020). Rapid detection of potato late blight using a loop-mediated isothermal amplification assay. J. Integr. Agric. 19 (5), 1274-1282. doi: 10.1016/S2095-3119(19)62816-9

Konstantinova, P. P., Bonants, J. M., Van Gent-Pelzer, M., Van Der Zouwen, P., and Van Der Bulk, R. (2002). Development of specific primers for detection and identification of Alternaria spp. in carrot material by PCR and comparison with blotter and plating assays. Mycol. Res. 106, 23-33. doi: 10.1017/ S0953756201005160

Krawczyk, K., Uszczyńska-Ratajczak, B., Majewska, A., and Borodynko-Filas, N. (2017). DNA microarray-based detection and identification of bacterial and viral pathogens of maize. J. Plant Dis. Prot. 124, 577-583. doi: 10.1007/s41348017-0098-4

Kukurba, K. R., and Montgomery, S. B. (2015). RNA Sequencing and Analysis. Cold Spring Harb. Protoc. 2015 (11), 951-969. doi: 10.1101/pdb.top084970

Kumar, P., Akhtar, J., Kandan, A., Kumar, S., Batra, R., and Dubey, S. C. (2016). "Advance detection techniques of phytopathogenic fungi: Current trends and future perspectives," in Current Trends in Plant Disease Diagnostics and Management Practices. Eds. P. Kumar, V. Gupta, A. Tiwari and M. Kamle (Cham: Springer), 265-298. doi: 10.1007/978-3-319-27312-9_12

Kumar, R., Gupta, A., Srivastava, S., Devi, G., Singh, V. K., Goswami, S. K., et al. (2020). "Diagnosis and Detection of Seed-Borne Fungal Phytopathogens," in Seed-Borne Diseases of Agricultural Crops: Detection, Diagnosis \& Management. Eds. R. Kumar and A. Gupta (Singapore: Springer), 107-142. doi: 10.1007/978-981-32-9046-4_5

Langrell, S. R. H., and Barbara, D. J. (2001). Magnetic capture hybridization for improved PCR detection of Nectria galligena from lignified apple extracts. Plant Mol. Biol. Rep. 19, 5-11. doi: 10.1007/BF02824073

Le, D. T., and Vu, N. T. (2017). Progress of loop-mediated isothermal amplification technique in molecular diagnosis of plant diseases. Appl. Biol. Chem. 60, 169-180. doi: 10.1007/s13765-017-0267-y

Lecomte, C., Alabouvette, C., Edel-Hermann, V., Robert, F., and Steinberg, C. (2016). Biological control of ornamental plant diseases caused by Fusarium oxysporum: A review. Biol. Control 101, 17-30. doi: 10.1016/j.biocontrol.2016.06.004

Leonard, K. J., and Szabo, L. J. (2005). Stem rust of small grains and grasses caused by Puccinia graminis. Mol. Plant Pathol. 6 (2), 99-111. doi: 10.1111/j.13643703.2005.00273.x 
Li, L., Zhang, S. Y., and Zhang, C. Q. (2019). Establishment of a rapid detection method for rice blast fungus based on one-step loop-mediated isothermal amplification (LAMP). Plant Dis. 103 (8), 1967-1973. doi: 10.1094/PDIS-11-18-1964-RE

Liebe, S., Daniela, S., Christ, D. S., Ehricht, R., and Varrelmann, M. (2016). Development of a DNA microarray-based assay for the detection of sugar beet root rot pathogens. Phytopathology 106 (1), 76-86. doi: 10.1094/PHYTO-0715-0171-R

Lin, H., Jiang, X., Yi, J., Wang, X., Zuo, R., Jiang, Z., et al. (2018). Molecular identification of Neofabraea species associated with bull's-eye rot on apple using rolling-circle amplification of partial EF-1 $\alpha$ sequence. Can. J. Microbiol. 64 (1), 57-68. doi: 10.1139/cjm-2017-0448

Ling, K. S., Wechter, W. P., Somai, B. M., Walcott, R. R., and Keinath, A. P. (2010). An improved real-time PCR system for broad-spectrum detection of Didymella bryoniae, the causal agent of gummy stem blight of cucurbits. Seed Sci. Technol. 38 (3), 692-703. doi: 10.15258/sst.2010.38.3.17

Loens, K., Goossens, H., de Laat, C., Foolen, H., Oudshoorn, P., Pattyn, S., et al. (2006). Detection of rhinoviruses by tissue culture and two independent amplification techniques, nucleic acid sequence-based amplification and reverse transcription-PCR, in children with acute respiratory infections during a winter season. J. Clin. Microbiol. 44, 166-171. doi: 10.1128/ JCM.44.1.166-171.2006

Luchi, N., Ghelardini, L., Belbahri, L., Quartier, M., and Santini, A. (2013). Rapid detection of Ceratocystis platani inoculum by quantitative real-time PCR assay. Appl. Environ. Microbiol. 79, 5394-5404. doi: 10.1128/AEM.01484-13

Luchi, N., Ioos, R., and Santini, A. (2020). Fast and reliable molecular methods to detect fungal pathogens in woody plants. Appl. Microbiol. Biotechnol. 104, 2453-2468. doi: 10.1007/s00253-020-10395-4

Lukumbuzya, M., Schmid, M., Pjevac, P., and Daims, H. (2019). A multicolor fluorescence in situ hybridization approach using an extended set of fluorophores to visualize microorganisms. Front. Microbiol. 10, 1383. doi: $10.3389 /$ fmicb.2019.01383

Ma, Z., and Michailides, T. J. (2007). Approaches for eliminating PCR inhibitors and designing PCR primers for the detection of phytopathogenic fungi. Crop Prot. 26, 145-161. doi: 10.1016/j.cropro.2006.04.014

Malapi-Wight, M., Demers, J. E., Veltri, D., Marra, R. E., and Crouch, J. A. (2016a). LAMP detection assays for Boxwood blight pathogens: A comparative genomic approach. Sci. Rep. 6, 26140. doi: 10.1038/srep26140

Malapi-Wight, M., Salgado-Salazar, C., Demers, J. E., Clement, D. L., Rane, K. K., and Crouch, J. A. (2016b). Sarcococca blight: Use of whole-genome sequencing for fungal plant disease diagnosis. Plant Dis. 100, 1093-1100. doi: 10.1094/ PDIS-10-15-1159-RE

Malcolm, G. M., Kuldau, G. A., Gugino, B. K., and Jiménez-Gasco, M. (2013). Hidden host plant associations of soilborne fungal pathogens: An ecological perspective. Phytopathology 103 (6), 538-544. doi: 10.1094/PHYTO-08-12-0192-LE

Mancini, V., Murolo, S., and Romanazzi, G. (2016). Diagnostic methods for detecting fungal pathogens on vegetable seeds. Plant Pathol. 65, 691-703. doi: $10.1111 /$ ppa. 12515

Manjunatha, C., Sharma, S., Kulshreshtha, D., Gupta, S., Singh, K., Bhardwaj, S. C., et al. (2018). Rapid detection of Puccinia triticina causing leaf rust of wheat by PCR and loop mediated isothermal amplification. PLoS One 13 (4), e0196409. doi: 10.1371/journal.pone.0196409

Marcinkowska, J. Z. (2002). Methods of finding and identification of pathogens in seeds. Plant Breed. Seed Sci. 46, 31-48.

Marčiulynas, A., Marčiulynienė, D., Lynikienė, J., Gedminas, A., Vaičiukynė, M., and Menkis, A. (2020). Fungi and Oomycetes in the Irrigation Water of Forest Nurseries. Forests 11, 459. doi: 10.3390/f11040459

Martinelli, F., Scalenghe, R., Davino, S., Panno, S., Scuderi, G., Ruisi, P., et al. (2015). Advanced methods of plant disease detection. A review. Agron. Sustain. Dev. 35, 1-25. doi: 10.1007/s13593-014-0246-1

McCartney, H. A., Foster, S. J., Fraaije, B. A., and Ward, E. (2003). Molecular diagnostics for fungal plant pathogens. Pest Manage. Sci. 59 (2), 129-142. doi: $10.1002 /$ ps.575

Meghvansi, M. K., Khan, M. H., Gupta, R., and Veer, V. (2013). Identification of a new species of Cercospora causing leaf spot disease in Capsicum assamicum in northeastern India. Res. Microbiol. 164 (9), 894-902. doi: 10.1016/ j.resmic.2013.08.003

Meng, J., and Doyle, M. P. (2002). Introduction. Microbiological food safety. Microbes Infect. 4 (4), 395-397. doi: 10.1016/S1286-4579(02)01552-6
Michalecka, M., Bryk, H., Poniatowska, A., and Puławska, J. (2016). Identification of Neofabraea species causing bull's eye rot of apple in Poland and their direct detection in apple fruit using multiplex PCR. Plant Pathol. 65, 643-654. doi: $10.1111 /$ ppa.12449

Midorikawa, G. E. O., Miller, R. N. G., Bittencourt, D. M., and de, C. (2018). "Molecular identification and detection of foodborne and feedborne mycotoxigenic fungi," in Molecular Techniques in Food Biology. Eds. A. F. El Sheikha, R. Levin and J. Xu (USA: John Wiley \& Sons Ltd), 385-407. doi: 10.1002/9781119374633.ch17

Milner, H., Ji, P., Sabula, M., and Wu, T. (2019). Quantitative polymerase chain reaction (Q-PCR) and fluorescent in situ hybridization (FISH) detection of soilborne pathogen Sclerotium rolfsii. Appl. Soil Ecol. 1362019, 86-92. doi: 10.1016/j.apsoil.2019.01.002

Mirmajlessi, S. M., Destefanis, M., Gottsberger, R. A., Mänd, M., and Loit, E. (2015). PCR-based specific techniques used for detecting the most important pathogens on strawberry: A systematic review. Syst. Rev. 4, 9. doi: 10.1186/ 2046-4053-4-9

Moffat, C. S., See, P. T., and Oliver, R. P. (2015). Leaf yellowing of the wheat cultivar Mace in the absence of yellow spot disease. Australas. Plant Pathol. 44, 161-166. doi: 10.1007/s13313-014-0335-2

Moradi, A., Almasi, M., Jafary, H., and Mercado-Blanco, J. (2014). A novel and rapid loop-mediated isothermal amplification assay for the specific detection of Verticillium dahliae. J. Appl. Microbiol. 116, 942-954. doi: 10.1111/jam.12407

Mori, Y., and Notomi, T. (2009). Loop-mediated isothermal amplification (LAMP): A rapid, accurate, and cost-effective diagnostic method for infectious diseases. J. Infect. Chemother. 15, 62-69. doi: 10.1007/s10156-0090669-9

Moter, A., and Göbel, U. B. (2000). Fluorescence in situ hybridization (FISH) for direct visualization of microorganisms. J. Microbiol. Methods 41, 85-112. doi: 10.1016/S0167-7012(00)00152-4

Murolo, S., De Miccolis Angelini, R. M., Faretra, F., and Romanazzi, G. (2018). Phenotypic and Molecular Investigations on Hypovirulent Cryphonectria parasitica in Italy. Plant Dis. 102 (3), 540-545. doi: 10.1094/PDIS-04-17-0517-RE

Musser, R. O., Hum-Musser, S. M., Gallucci, M., DesRochers, B., and Brown, J. K. (2014). Microarray analysis of tomato plants exposed to the nonviruliferous or viruliferous whitefly vector harboring pepper golden mosaic virus. J. Insect Sci. 14 (1), 230. doi: 10.1093/jisesa/ieu092

Nagamine, K., Hase, T., and Notomi, T. (2002). Accelerated reaction by loopmediated isothermal amplification using loop primers. Mol. Cell Probes 16 (3), 223-229. doi: 10.1006/mcpr.2002.0415

Nagrale, D. T., Sharma, L., Kumar, S., and Gawande, S. P. (2016). "Recent Diagnostics and Detection Tools: Implications for Plant Pathogenic Alternaria and Their Disease Management," in Current Trends in Plant Disease Diagnostics and Management Practices. Ed. P. Kumar, A. Gupta, A. Tiwari and M. Kamle. (Switzerland: Springer), 111-164. doi: 10.1007/978-3319-27312-9_5

Nam, M., Kim, J. S., Lim, S., Park, C. Y., Kim, J. G., Choi, H. S., et al. (2014). Development of the large-scale oligonucleotide chip for the diagnosis of plant viruses and its practical use. Plant Pathol. J. 30, 51-57. doi: 10.5423/ PPJ.OA.08.2013.0084

Narayanasamy, P. (2011). "Diagnosis of fungal diseases of plants," in Microbial plant pathogens-detection and disease diagnosis (Dordrecht: Springer), 273284. doi: 10.1007/978-90-481-9735-4_5

Ndayihanzamaso, P., Karangwa, P., Mostert, D., Mahuku, G., Blomme, G., Beed, F., et al. (2020). The development of a multiplex PCR assay for the detection of Fusarium oxysporum f. sp. cubense lineage VI strains in East and Central Africa. Eur. J. Plant Pathol. 158, 495-509. doi: 10.1007/s10658-020-02092-9

Nezhad, A. S. (2014). Future of portable devices for plant pathogen diagnosis. Lab. Chip 14, 2887-2904. doi: 10.1039/C4LC00487F

Nikitin, M., Deych, K., Grevtseva, I., Girsova, N., Kuznetsova, M., Pridannikov, M., et al. (2018). Preserved microarrays for simultaneous detection and identification of six fungal potato pathogens with the use of real-time PCR in matrix format. Biosensors 8, 129. doi: 10.3390/bios8040129

Notomi, T., Okayama, H., Masubuchi, H., Yonekawa, T., Watanabe, K., Amino, N., et al. (2000). Loop-mediated isothermal amplification of DNA. Nucleic Acids Res. 28, e63. doi: 10.1093/nar/28.12e63

Ordóñez, N., Salacinas, M., Mendes, O., Seidl, M. F., Meijer, H. J. G., Schoen, C. D., et al. (2019). A loop-mediated isothermal amplification (LAMP) assay based on 
unique markers derived from genotyping by sequencing data for rapid in planta diagnosis of Panama disease caused by Tropical Race 4 in banana. Plant Pathol. 68, 1682-1693. doi: 10.1111/ppa.13093

Ortega, S. F., Tomlinson, J., Hoggetts, J., Spadaro, D., Gullino, M. L., and Boonham, N. (2018). Development of Loop-mediated isothermal amplification assay for the detection of seedborne fungal pathogens Fusarium fujikuroi and Magnaporthe oryzae in rice seed. Plant Dis. 102 (8), 1549-1558. doi: 10.1094/PDIS-08-17-1307-RE

Pallás, V., Sánchez-Navarro, J. A., and Delano, J. (2018). Recent advances on the multiplex molecular detection of plant viruses and viroids. Front. Microbiol. 9, 2087. doi: $10.3389 /$ fmicb. 2018.02087

Panek, J., and Frąc, M. (2019). Loop-mediated isothermal amplification (LAMP) approach for detection of heat-resistant Talaromyces flavus species. Sci. Rep. 9 (1), 5846. doi: 10.1038/s41598-019-42275-x

Panno, S., Ruiz-Ruiz, S., Caruso, A. G., Alfaro-Fernandez, A., Font San Ambrosio, M. I., and Davino, S. (2019). Real-time reverse transcription polymerase chain reaction development for rapid detection of Tomato brown rugose fruit virus and comparison with other techniques. PeerJ 7, e7928. doi: 10.7717/peerj.7928

Panno, S., Matić, S., Tiberini, A., Caruso, A. G., Bella, P., Torta, L., et al. (2020). Loop Mediated Isothermal Amplification: Principles and Applications in Plant Virology. Plants 9 (4), 461. doi: 10.3390/plants9040461

Parkinson, L. E., Le, D. P., and Dann, E. K. (2019). Development of three loop-mediated isothermal amplification (LAMP) assays for the rapid detection of Calonectria ilicicola, Dactylonectria macrodidyma, and the Dactylonectria genus in avocado roots. Plant Dis. 103 (8), 1865-1875. doi: 10.1094/PDIS-11-18-2005-RE

Pecchia, S., Caggiano, B., Lio, D., Cafà, G., Le Floch, G., and Baroncelli, R. (2019). Molecular detection of the seed-borne pathogen Colletotrichum lupini targeting the hyper-variable IGS region of the ribosomal cluster. Plants 8 (7), 222. doi: 10.3390/plants8070222

Pépin, N., Punja, Z. K., and Joly, D. L. (2018). Occurrence of powdery mildew caused by Golovinomyces cichoracearum sensulato on Cannabis sativa in Canada. Plant Dis. 102, 2644. doi: 10.1094/PDIS-04-18-0586-PDN

Porto, B. N., Caixeta, E. T., Mathioni, S. M., Vidigal, P., Zambolim, L., Zambolim, E. M., et al. (2019). Genome sequencing and transcript analysis of Hemileia vastatrix reveal expression dynamics of candidate effectors dependent on host compatibility. PLoS One 14 (4), e0215598. doi: 10.1371/journal.pone.0215598

Potgieter, L., Feurtey, A., Dutheil, J. Y., and Stukenbrock, E. H. (2020). On Variant Discovery in Genomes of Fungal Plant Pathogens. Front. Microbiol. 11, 626. doi: $10.3389 /$ fmicb.2020.00626

Prasannath, K., Galea, V. J., and Akinsanmi, O. A. (2020). Characterisation of leaf spots caused by Neopestalotiopsis clavispora and Colletotrichum siamense in macadamia in Australia. Eur. J. Plant Pathol. 156, 1219-1225. doi: 10.1007/ s10658-020-01962-6

Pryce, T. M., Palladino, S., Kay, I. D., and Coombs, G. W. (2003). Rapid identification of fungi by sequencing the ITS1 and ITS2 regions using an automated capillary electrophoresis system. Med. Mycol. 41 (5), 369-381. doi: $10.1080 / 13693780310001600435$

Qiao, T. M., Zhang, J., Li, S. J., Han, S., and Zhu, T. H. (2016). Development of nested PCR, multiplex PCR, and loop-mediated isothermal amplification assays for rapid detection of Cylindrocladium scoparium on Eucalyptus. Plant Pathol. J. 32 (5), 414-422. doi: 10.5423/PPJ.OA.03.2016.0065

Qin, D. (2019). Next-generation sequencing and its clinical application. Cancer Biol. Med. 16 (1), 4-10. doi: 10.20892/j.issn.2095-3941.2018.0055

Raj, M., Nath, V. S., Sankar, M. S., Pravi, V., Archana, P. V., Jeeva, M. L., et al. (2013). A highly sensitive nested-PCR method using a single closed tube for the detection of Colletotrichum gloeosporioides causing greater yam anthracnose. J. Root Crops 39 (2), 163-167.

Rajesh, T., and Jaya, M. (2017). "Next-generation sequencing methods," in Current Developments in Biotechnology and Bioengineering. Eds. P. Gunasekaran, S. Noronha and A. Pandey (Amsterdam: Elsevier), 143-158. doi: 10.1016/B978-0-444-63667-6.00007-9

Ritz, K. (2005). "Fungi," in Encyclopedia of Soils in the Environment. Ed. D. Hillel (Oxford: Elsevier), 110-119. doi: 10.1016/B0-12-348530-4/00147-8

Rodriguez-Moreno, L., Ebert, M. K., Bolton, M. D., and Thomma, B. P. (2018). Tools of the crook- infection strategies of fungal plant pathogens. Plant J. 93, 664-674. doi: 10.1111/tpj.13810

Rollins, L., Coats, K., Elliott, M., and Chastagner, G. (2016). Comparison of five detection and quantification methods for Phytophthora ramorum in stream and irrigation water. Plant Dis. 100, 1202-1211. doi: 10.1094/PDIS-11-151380-RE

Sankarana, S., Mishraa, S., Ehsania, R., and Davis, C. (2010). A review of advanced techniques for detecting plant diseases. Comput. Electron Agr. 72, 1-13. doi: 10.1016/j.compag.2010.02.007

Sarrocco, S., and Vannacci, G. (2018). Preharvest application of beneficial fungi as a strategy to prevent postharvest mycotoxin contamination: a review. Crop Prot. 110, 160-170. doi: 10.1016/j.cropro.2017.11.013

Schaad, N. W., Cheong, S. S., Tamaki, S., Hatziloukas, E., and Panopoulos, N. J. (1995). A combined biological and enzymatic amplification (BIO-PCR) technique to detect Pseudomonas syringae pv. phaseolicola in bean extracts. Phytopathology 85, 243-248. doi: 10.1094/Phyto-85-243

Schadt, E. E., Turner, S., and Kasarskis, A. (2010). A window into third-generation sequencing. Hum. Mol. Genet. 19 (R2), R227-R240. doi: 10.1093/hmg/ddq416

Schena, L., Nigro, F., Ippolito, A, and Gallitelli, D. (2004). Real-time quantitative PCR: a new technology to detect and study phytopathogenic and antagonistic fungi. Eur. J. Plant Pathol. 110, 893-908. doi: 10.1007/s10658-004-4842-9

Schena, L., Li Destri Nicosia, M. G., Sanzani, S. M., Faedda, R., Ippolito, A., and Cacciola, S. O. (2013). Development of quantitative PCR detection methods for phytopathogenic fungi and oomycetes. J. Plant Pathol. 95, 7-24. doi: 10.4454/ JPP.V95I1.016

Shakoori, A. R. (2017). "Fluorescence in situ hybridization (FISH) and its applications," in Chromosome Structure and Aberrations. Eds. T. A. Bhat and A. A. Wani (India: Springer), 343-367. doi: 10.1007/978-81-322-3673-3_16

Sharma, P., and Sharma, S. (2016). "Paradigm shift in plant disease diagnostics: A journey from conventional diagnostics to nano-diagnostics," in Current Trends in Plant Disease Diagnostics and Management Practices. Eds. P. Kumar, V. Gupta, A. Tiwari and M. Kamle (Cham: Springer), 237-264. doi: 10.1007/9783-319-27312-9_11

Shuey, M. M., Drees, K. P., Lindner, D. L., Keim, P., and Foster, J. T. (2014). Highly sensitive quantitative PCR for the detection and differentiation of Pseudogymnoascus destructans and other Pseudogymnoascus species. Appl. Environ. Microbiol. 80, 1726-1731. doi: 10.1128/AEM.02897-13

Shuping, D., and Eloff, J. N. (2017). The use of plants to protect plants and food against fungal pathogens: A review. Afr. J. Tradit. Complement Altern. Med. 14 (4), 120-127. doi: 10.21010/ajtcam.v14i4.14

Sikdar, P., Okubara, P., Mazzola, M., and Xiao, C. L. (2014). Development of PCR assays for diagnosis and detection of the pathogens Phacidiopycnis washingtonensis and Sphaeropsis pyriputrescens in apple fruit. Plant Dis. 98 (2), 241-246. doi: 10.1094/PDIS-05-13-0495-RE

Silvar, C., Duncan, J. M., Cooke, D. E. L., Willians, N. A., Diaz, J., and Merino, F. (2005). Development of specific PCR primers for identification and detection of Phytiphthora capsici Leon. Eur. J. Plant Pathol. 112, 43-52. doi: 10.1007/ s10658-004-8232-0

Sint, D., Raso, L., and Traugott, M. (2012). Advances in multiplex PCR: balancing primer efficienciesand improving detection success. Methods Ecol. Evol. 3 (5), 898-905. doi: 10.1111/j.2041-210X.2012.00215.x

Stehliková, D., Luchi, N., Aglietti, C., Pepori, A. L., Diez, J. J., and Santini, A. (2020). Real-time loop-mediated isothermal amplification assay for rapid detection of Fusarium circinatum. BioTechniques 69 (7), 1-7. doi: 10.2144/btn-2019-0168

Sun, G., Liu, J., Li, G., Zhang, X., Chen, T., Chen, J., et al. (2015). Quick and accurate detection and quantification of Magnaporthe oryzae in rice using realtime quantitative polymerase chain reaction. Plant Dis. 99, 219-224. doi: 10.1094/PDIS-05-14-0485-RE

Tan, D. H. S., Sigler, L., Gibas, C. F. C., and Fong, I. W. (2008). Disseminated fungal infection in a renal trans- plant recipient involving Macrophomina phaseolina and Scytalidium dimidiatum: Case report and review of taxonomic changes among medically important members of the Botryosphaeriaceae. Med. Mycol. 46, 285-292. doi: 10.1080/13693780701759658

Tanner, N. A., Zhang, Y., and Evans, T. C. (2015). Visual detection of isothermal nucleic acid amplification using pH-sensitive dyes. BioTechniques 58, 59-68. doi: $10.2144 / 000114253$

Thind, B. S. (2015). "Diagnosis and management of bacterial plant diseases," in Recent advances in the diagnosis and management of plant diseases. Ed. L. P. Awasthi (India: Springer), 101-117. doi: 10.1007/978-81-322-2571-3_10

Tiberini, A., and Barba, M. (2012). Optimization and improvement of oligonucleotide microarray-based detection of tomato viruses and pospiviroids. J. Virol. Methods 185, 43-51. doi: 10.1016/j.jviromet.2012.05.028 
Tör, M., and Woods-Tör, A. (2017). "Fungal and oomycete diseases," in Encyclopedia of applied plant sciences. Eds. B. Thomas, B. G. Murray and D. J. Murphy (New York, USA: Academic Press), 77-82. doi: 10.1016/B978-0-12394807-6.00053-8

Tsui, C. K., Woodhall, J., Chen, W., Lévesque, C. A., Lau, A., Schoen, C. D., et al. (2011). Molecular techniques for pathogen identification and fungus detection in the environment. IMA Fungus 2, 177-189. doi: 10.5598/imafungus.2011.02.02.09

Úrbez-Torres, J. R., Haag, P., Bowen, P., Lowery, T., and O’Gorman, D. T. (2015). Development of a DNA macroarray for the detection and identification of fungal pathogens causing decline of young grapevines. Phytopathology 105 (10), 1373-1388. doi: 10.1094/PHYTO-03-15-0069-R

van Emmerik, C. L., Gachulincova, I., Lobbia, V. R., Daniëls, M. A., Heus, H. A., Soufi, A., et al. (2020). Ramified rolling circle amplification for synthesis of nucleosomal DNA sequences. Anal. Biochem. 588, 113469. doi: 10.1016/ j.ab.2019.113469

Walcott, R. R., Gitaitis, R. D., and Langston, D. B. (2004). Detection of Botrytis aclada in onion seed using magnetic capture hybridization and the polymerase chain reaction. Seed Sci. Technol. 32, 425-438. doi: 10.15258/sst.2004.32.2.14

Waliullah, S., Ling, K. S., Cieniewicz, E. J., Oliver, J. E., Ji, P., and Ali, M. E. (2020). Development of loop-mediated isothermal amplification assay for rapid detection of cucurbit leaf crumple virus. Int. J. Mol. Sci. 21 (5), 1756. doi: 10.3390/ijms21051756

Wang, X., Tang, C., Chen, J., Buchenauer, H., Zhao, J., Han, Q., et al. (2009). Detection of Puccinia striiformis in latently infected wheat leaves by nested polymerase chain reaction. J. Phytopathol. 157, 490-493. doi: 10.1111/j.14390434.2008.01521.x

Wenneker, M., and Thomma, B. P. H. J. (2020). Latent postharvest pathogens of pome fruit and their management: from single measures to a systems intervention approach. Eur. J. Plant Pathol. 156, 663-681. doi: 10.1007/ s10658-020-01935-9

Wernecke, M., and Mullen, C. (2014). "Molecular biology, Molecular biology in microbiological analysis," in Encyclopedia of Food Microbiology. Eds. C. A. Batt and M. L. Tortorello (Oxford: Academic Press), 808-814. doi: 10.1016/B978-012-384730-0.00225-1

Withers, S., Gongora-Castillo, E., Gent, D., Thomas, A., Ojiambo, P. S., and QuesadaOcampo, L. M. (2016). Using next-generation sequencing to develop molecular diagnostics for Pseudoperonospora cubensis, the cucurbit downy mildew pathogen. Phytopathology 106 (10), 1105-1116. doi: 10.1094/PHYTO-10-15-0260-FI

Wu, J. Y., Hu, X. R., and Zhang, C. Q. (2019). Molecular detection of QoI resistance in Colletotrichum gloeosporioides causing strawberry anthracnose based on loop-mediated isothermal amplification assay. Plant Dis. 103 (6), 1319-1325. doi: 10.1094/PDIS-09-18-1593-RE

Yan, H., Zhang, J., Ma, D., and Yin, J. (2019). qPCR and loop mediated isothermal amplification for rapid detection of Ustilago tritici. PeerJ 7, e7766. doi: 10.7717/ peerj.7766
Yang, Y., Zuzak, K., and Feng, F. (2016). An improved simple method for DNA extraction from fungal mycelia. Can. J. Plant Pathol. 38, 476-482. doi: 10.1080/ 07060661.2016.1243585

Yang, X., Qi, Y., Al-Attala, M. N., Gao, Z., Yi, X., Zhang, A., et al. (2019). Rapid detection of Alternaria species involved in pear black spot using loop-mediated isothermal amplification. Plant Dis. 103 (12), 3002-3008. doi: 10.1094/PDIS01-19-0149-RE

Yang, K., Lee, I., and Nam, S. (2017). Development of a rapid detection method for Peronospora destructor using loop-mediated isothermal amplification (LAMP). HortScience 52 (9), S413. doi: 10.21273/HORTSCI.52.9S.S1

Yang, X., Hameed, U., Zhang, A. F., Zang, H. Y., Gu, C. Y., Chen, Y., et al. (2017). Development of a nested-PCR assay for the rapid detection of Pilidiella granati in pomegranate fruit. Sci. Rep. 7, 40954. doi: 10.1038/srep40954

Yao, X., Li, P., Xu, J., Zhang, M., Ren, R., and Liu, G. (2016). Rapid and sensitive detection of Didymella bryoniae by visual loop-mediated isothermal amplification assay. Front. Microbiol. 7, 1372. doi: 10.3389/fmicb.2016.01372

Zhang, N., McCarthy, M. C., and Smart, C. D. (2008). A macroarray system for the detection of fungal and oomycete pathogens of Solanaceous crops. Plant Dis. 92 (6), 953-960. doi: 10.1094/PDIS-92-6-0953

Zhang, Y., Zhang, S., Liu, X., Wen, H., and Wang, M. (2010). A simple method of genomic DNA extraction suitable for analysis of bulk fungal strains. Lett. Appl. Microbiol. 51, 114-118. doi: 10.1111/j.1472-765X.2010.02867.x

Zhang, S. Y., Dai, D. J., Wang, H. D., and Zhang, C. Q. (2019). One-step loopmediated isothermal amplification (LAMP) for the rapid and sensitive detection of Fusarium fujikuroi in bakanae disease through NRPS31, an important gene in the gibberellic acid bio-synthesis. Sci. Rep. 9, 3726. doi: 10.1038/s41598-019-39874-z

Zhao, X., Lin, C. W., Wang, J., and Oh, D. H. (2014). Advances in rapid detection methods for foodborne pathogens. J. Microbiol. Biotechnol. 24, 297-312. doi: 10.4014/jmb.1310.10013

Zhao, Y. Q., Wu, Y. H., Zhao, X. X., An, M. N., and Chen, J. G. (2014). Study on the Taqman real-time PCR to the detection and quantification of Rhizoctonia solani AG-3 of tobacco target spot. Adv. Mater. Res. 1010-1012, 80-83. doi: 10.4028/www.scientific.net/AMR.1010-1012.80

Conflict of Interest: The authors declare that the research was conducted in the absence of any commercial or financial relationships that could be construed as a potential conflict of interest.

Copyright (c) 2021 Hariharan and Prasannath. This is an open-access article distributed under the terms of the Creative Commons Attribution License (CC BY). The use, distribution or reproduction in other forums is permitted, provided the original author(s) and the copyright owner(s) are credited and that the original publication in this journal is cited, in accordance with accepted academic practice. No use, distribution or reproduction is permitted which does not comply with these terms. 